\title{
Selachians and actinopterygians from the Upper Jurassic of Tendaguru, Tanzania
}

\author{
Gloria Arratia $^{1}$, Jürgen Kriwet ${ }^{2} \&$ Wolf-Dieter Heinrich ${ }^{1}$ \\ With 9 figures and 2 tables
}

\begin{abstract}
The first Late Jurassic selachian and actinopterygian fishes of Tendaguru in Tanzania were collected by the German-Tendaguru expedition in 1909-1913. They are represented mainly by occasional teeth of a neoselachian (Sphenodus) and several specimens of a neopterygian (Lepidotes). New material collected by the German-Tanzanian Tendaguru expedition in 2000 includes additional selachians recovered from clay stones at site Dwa 5a and isolated actinopterygian remains. At least three hybodonts (Hybodus sp., Hybodontidae indet., Lonchidion sp.) and a new neoselachian batoid are presented here. This assemblage is endemic to Tendaguru. A new batoid genus and species, Engaibatis schultzei, is described, which is the oldest record of a ray from Gondwana. The actinopterygians are represented by scarce and disarticulated scales of Lepidotes, 'pholidophoriform'-like scales, and teleostean vertebrae. This material includes new biogeographic records for Africa. In addition, a synopsis of Jurassic fishes from Africa is presented.
\end{abstract}

Key words: Fishes, Engaibatis schultzei n. gen. and n. sp., Late Jurassic, Tendaguru, Tanzania, East Africa.

\section{Zusammenfassung}

Die Fischfauna aus dem Oberjura von Tendaguru ist bisher nur unzureichend bekannt. Das erste Material, das von der Deutschen Tendaguru-Expedition (1909-1913) gesammelt wurde, besteht fast nur aus einigen wenigen isolierten Zähne des Haies Sphenodus und mehreren Exemplaren des Actinopterygiers Lepidotes. Neue Funde, die während der Deutsch-TansanischenTendaguru-Expedition im Jahre 2000 geborgen wurden, erlauben es, mehrere Taxa zu beschreiben, die aus dem Oberjura Afrikas noch nicht bekannt waren. Anhand von Zähnen konnten mindestens drei zu den ursprünglichen Hybodontiern zählende Taxa (Hybodus sp., Hybodontidae indet., Lonchidion sp.) nachgewiesen sowie ein für Tendaguru neuer Rochen (Engaibatis schultzei n. gen. and n. sp.) festgestellt werden. Actinopterygier sind durch wenige und disartikulierte Schuppen von Lepidotes und einer 'pholidophoriden'-ähnlichen Form sowie durch Wirbel von Teleosteern vertreten. Das neue Material gibt wichtige Hinweise auf die paläobiogeographische Verbreitung der spätjurassischen Fische. Es wird ein Überblick über die bisher bekannten jurassischen Fischfaunen Afrikas gegeben.

Schlüsselwörter: Fische, Engaibatis schultzei n. gen. und n. sp., Oberjura, Tendaguru, Tanzania, Ostafrika.

\section{Introduction}

The first fish remains from the Tendaguru Beds were reported by Hennig (1914a). Prior to this study, fishes were unknown from the Mesozoic of East Africa. Hennig recognized selachians (Orthacodus, now interpreted as Sphenodus), a pycnodontid, and semionotids described as Lepidotus minor (figured as Lepidotus aff. minor), Lepidotus sp., and remains of fishes identified as Genus indet. (Table 1). Most of the material reported by Hennig consists of moderately well preserved teeth and scales. However, some speci- mens assigned to Lepidotus minor are reasonably complete individuals from a monospecific mass-accumulation (Hennig 1914a: 296). Nearly 90 years elapsed until the subsequent study of fish remains from the Tendaguru Beds. Arratia \& Schultze (1999) restudied the available fish material and referred the Lepidotus specimens from Tendaguru to a new species, Lepidotes tendaguruensis. Recent field work of the GermanTanzanian Tendaguru expedition (Heinrich et al. 2001) resulted in the discovery of further fish remains. This new material, collected mainly in exposures of the Tingutinguti and Dwanika stream

\footnotetext{
1 Museum für Naturkunde der Humboldt Universität, Institut für Paläontologie, Invalidenstr. 43, D-10115 Berlin, Germany.

2 Department of Earth Sciences, University of Bristol, Wills Memorial Building, Queens Road, Bristol BS8 1RJ, UK. Received April, accepted June 2002
} 


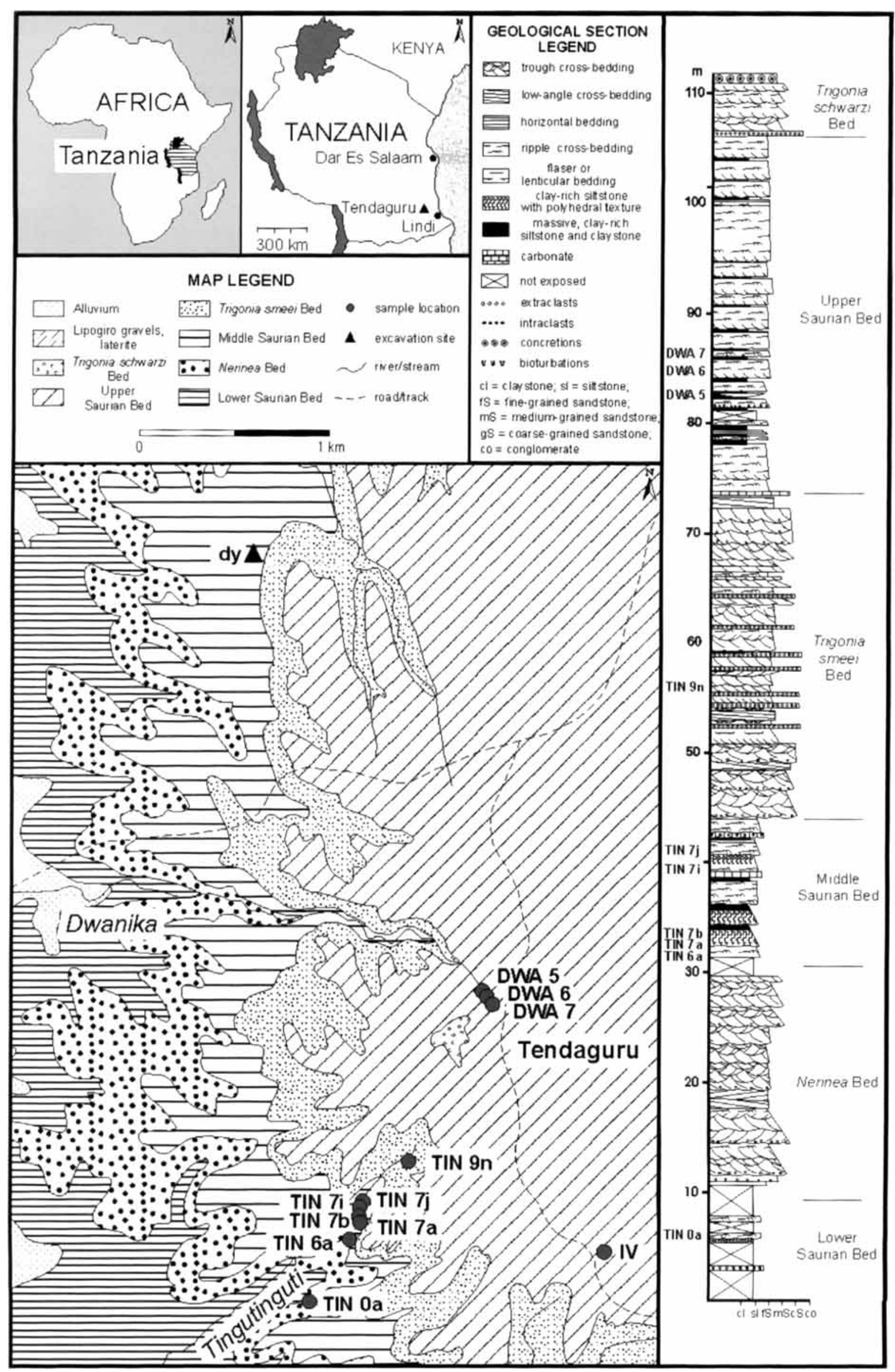


sections, differs from the hitherto known fish fauna of the Tendaguru Beds in its greater taxonomic diversity. Several taxa previously unknown from the Late Jurassic of East Africa are recognized.

\section{Geological and paleontological setting}

Tendaguru Hill is located in southeastern Tanzania, about $60 \mathrm{~km}$ northwest of the seaport of Lindi. Details of the geological structure of the Tendaguru region and the stratigraphy of the famous Tendaguru Beds, which have produced a diverse dinosaur assemblage, are given by Hennig (1914b), Janensch (1914, 1925), Aitken (1961), and Russell et al. (1980), with important additions and refinements by Bussert (2001), Heinrich et al. (2001), and Aberhan et al. (2002, this volume).

The stratigraphic sequence exposed at Tendaguru Hill consists of three dinosaur-bearing strata, the Lower, Middle, and Upper Saurian Bed, separated from one another by three marine sandstone units, the Nerinea Bed, the Trigonia smeei Bed, and the Trigonia schwarzi Beds (Figs 1 and 2). The age of the Tendaguru Beds is considered to be Late Jurassic to Early Cretaceous. The age of the fish-bearing strata will be discussed below.

The fish remains described here come from the Lower and the Middle Saurian Beds, the Trigonia smeei Bed, and the Upper Saurian Bed (Figs 1 and 2, Tab. 2). They were collected from sites in the Dwanika stream section and the Tingutinguti stream section (Fig. 1, Tab. 2), and complemented by material from previous excavation localities of the German-Tendaguru expedition (IV, XX, dy) located in the surroundings of Tendaguru Hill. Most of the material has been found in the fine-grained sandstones in the channel facies, followed by specimens recovered from fine-grained sediments in the tidal flat facies (Tab.2). The data on the petrography and depositional environment of the fish-bearing strata are summarized in Table 2. All the material described here was obtained from acetic acid residues of rock samples processed for recovery of microvertebrates.
The biostratigraphic position of fish-bearing deposits in the Tendaguru Beds can be outlined as follows: The age of the Lower Saurian Bed is tentatively considered to be Oxfordian, since the of the Nerinea Bed, from which fish remains have yet to be recovered, is Oxfordian ? to Late Kimmeridgian in age (Aberhan et al. 2002). Based on charophyta, the middle part of the Trigonia smeei Bed is referrable to the early Tithonian (Heinrich et al. 2001, Aberhan et al. 2002). A bone bed $(\mathrm{Jg})$ in the Middle Saurian Bed at the Tendaguru site dy was considered to be either Kimmeridgian (Schudack 1999) or Kimmeridgian to Tithonian (Schrank 1999) in age. Ammonites collected from the Nerinea Bed and the Trigonia smeei Bed indicate a Late Kimmeridgian to Tithonian age of the Middle and Upper Saurian Bed (Aitken 1961, Russell et al. 1980). Ammonites (Aitken 1961) and palynomorphs (Heinrich et al. 2001) refer the Trigonia schwarzi Bed to the Early Cretaceous (possibly Valangian to Hauterivian: Aberhan et al. 2002).

\section{Synopsis of Jurassic fishes from Africa}

While the Cretaceous fish fauna of Africa has attracted much scientific attention, there are comparably few studies on Triassic and Jurassic fishes (for references see Murray 2000). Isolated teeth and scales referred to Colobodus cf. maximus, Colobodus sp., Hybodus cf. minor, and Eugnathus (= Furo) from the Lugh Series of northern Somalia by d'Erasmo (1931) are considered to be Late Triassic or Early Jurassic in age (MacFadyen 1933). Goodwin et al. (1999) reported scales from the Late Triassic-Early Jurassic Adigrat Sandstones of Ethiopia west of Addis Ababa. Gaudant et al. (1972) reported the presence of a small teleost from the Toarcian of Tunisia, which was identified as Leptolepis. In general, there are few Early Jurassic fish remains reported from Africa.

Saint-Seine (1955) and Saint-Seine \& Casier (1962) described two fish faunas from the Jurassic Stanleyville Beds of the interior of what was then the Congo. The deposits were interpreted as Kimmeridgian in age by Saint-Seine (1955) but are now considered to be Aalenian-Batho-

Fig. 1. Map of the Tendaguru area in southeastern Tanzania with a synthetic section of the Tendaguru Beds and the location of the sites and the position of the fish-bearing horizons. Source: Hennig (1914a), Janensch (1914b, 1925), Heinrich et al. (2001), and data from the German Tanzanian Tendaguru expedition 2000 (after R. Bussert). 


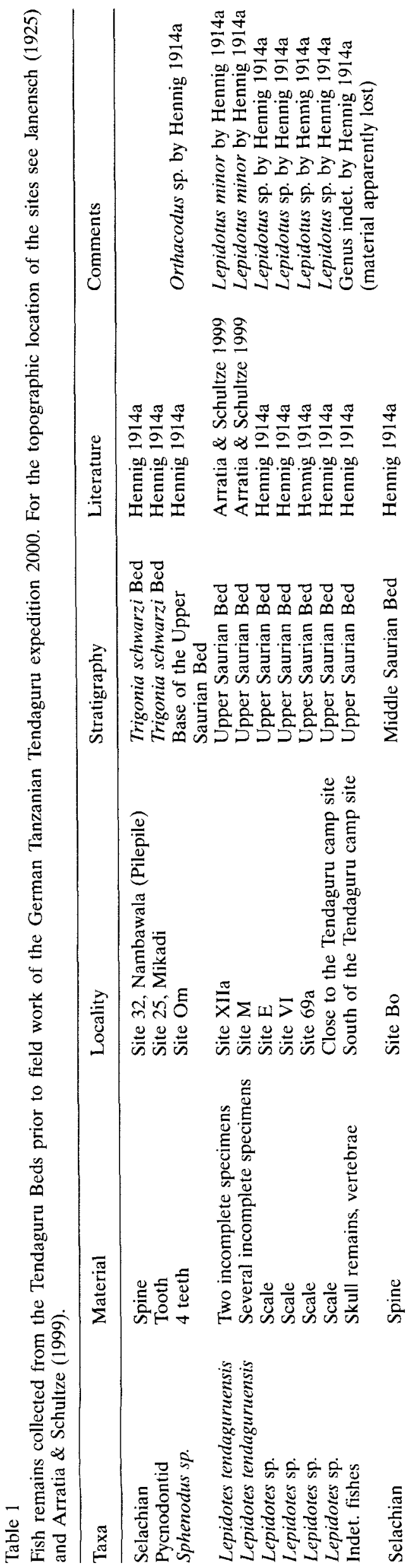

nian (Colin 1994). A highly diverse fauna including coelacanths but no selachians was described from supposed fresh water deposits (Saint-Seine 1955). The marine fish fauna of the Stanleyville beds fauna, which comes from limestones near Songa, contains a hybodont shark (Hybodus songaensis) and typical Jurassic actinopterygians such as Caturus, Ophiopsis, Pholidophorus and Paraclupavus among others (Saint-Seine \& Casier 1962).

Late Jurassic fishes from the African continent are known thus far only from North Africa, Somalia, Ethiopia, Tanzania, Zaire, and Cameroon, while Jurassic fishes remains still are to be documented from South Africa (e.g., Oelofson 1981, Goodwin et al. 1999).

Hennig (1913a) published a synopsis of fossil fish remains from Africa. He reported the presence of Lepidotes manni Hennig, 1913 in the Late Jurassic of Adamaua in Cameroon (Hennig 1913b).

In 1960, d'Erasmo described isolated scales and teeth of selachians and actinopterygians from several Late Jurassic localities in the Lug Series of Somalia, which are probably Tithonian in age. $\mathrm{He}$ reported Lepidotes, undetermined pycnodonts, Hybodus, Priohybodus, and Orthacodus.

Schaeffer \& Patterson (1984) recorded Hybodus and Lepidotes in the Late Jurassic of North Africa in a general overview of African Jurassic fishes. Moreover, they indicated the presence of the selachians Hybodus and Asteracanthus (Tithonian?), Sphenodus (Upper Jurassic), and Hexanchus (Kimmeridgian) and an array of actinopterygians in the Erythrean Trough of Zaire. Unfortunately, they did not provide references but it is most likely that the occurrences of $\mathrm{Hy}$ bodus and the actinopterygians are based mainly on the publications by Sainte-Seine (1955) and Saint-Seine \& Casier (1962).

The Mugher Mudstone Formation in Ethiopia has yielded many fish remains from several localities (Goodwin et al. 1999). In contrast to Schmidt \& Werner (1998) who assigned an Early Cretaceous (Neocomian) age to the fish bearing layers, Goodwin et al. (1999) suggested a Late Jurassic age for the fish remains based on palynological evidence. They identified isolated teeth of Hybodus (probably a species unique to Ethiopia), Priohybodus, 'Rhinobatos', scales and teeth of Lepidotes, a fragmentary dentition of a pycnodont erroneously attributed to Pycnodus, and tooth plates of the lungfish Asiatoceratodus tiguidensis. 


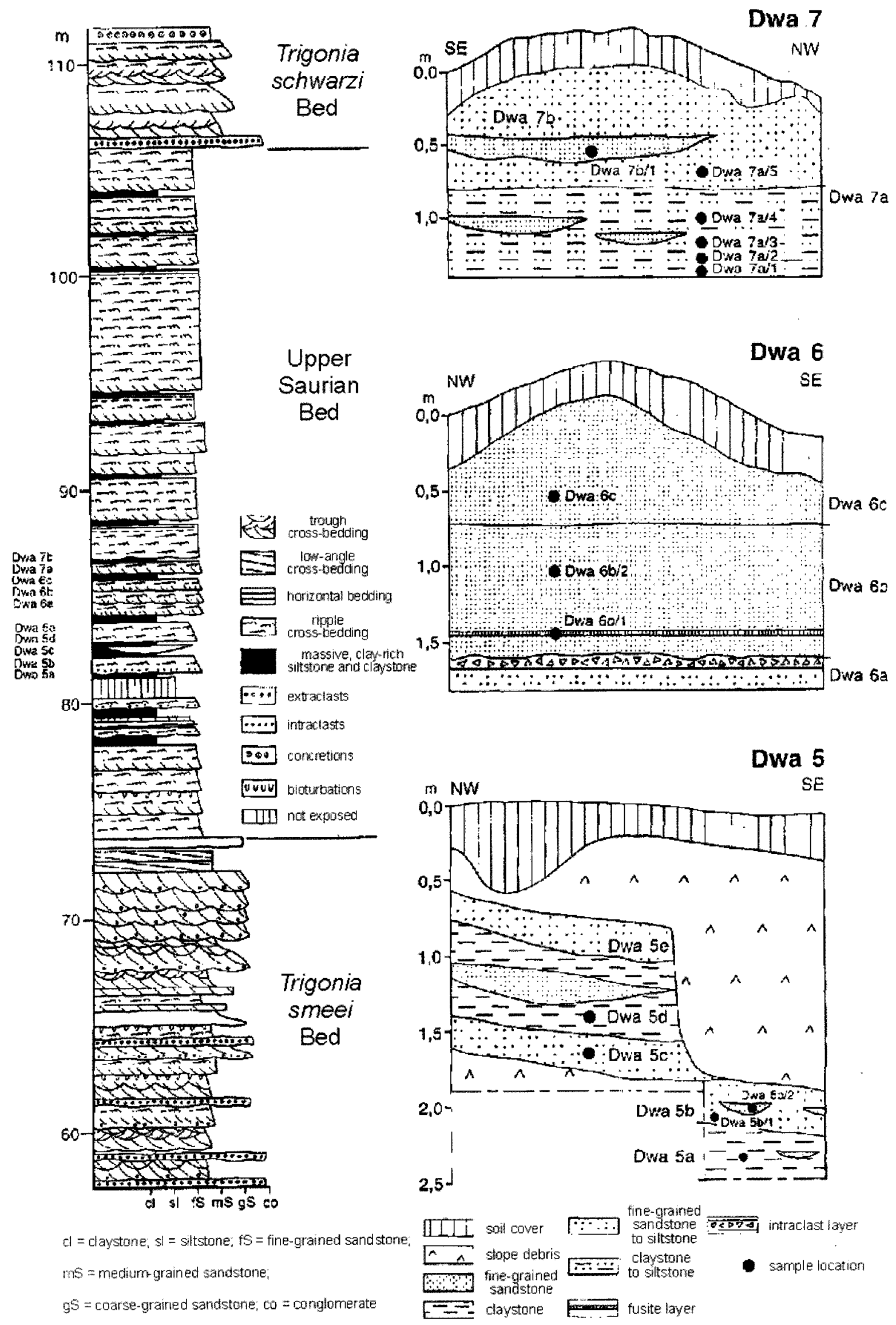

Fig. 2. Synthetic section of the middle and upper part of the Tendaguru Beds (on left) indicating the position of the fishbearing horizon, shown in detail in the sections Dwa 5 to Dwa 7 (on right). Source: German Tanzanian Tendaguru expedition 2000 (after R. Bussert and W.-D. Heinrich). 


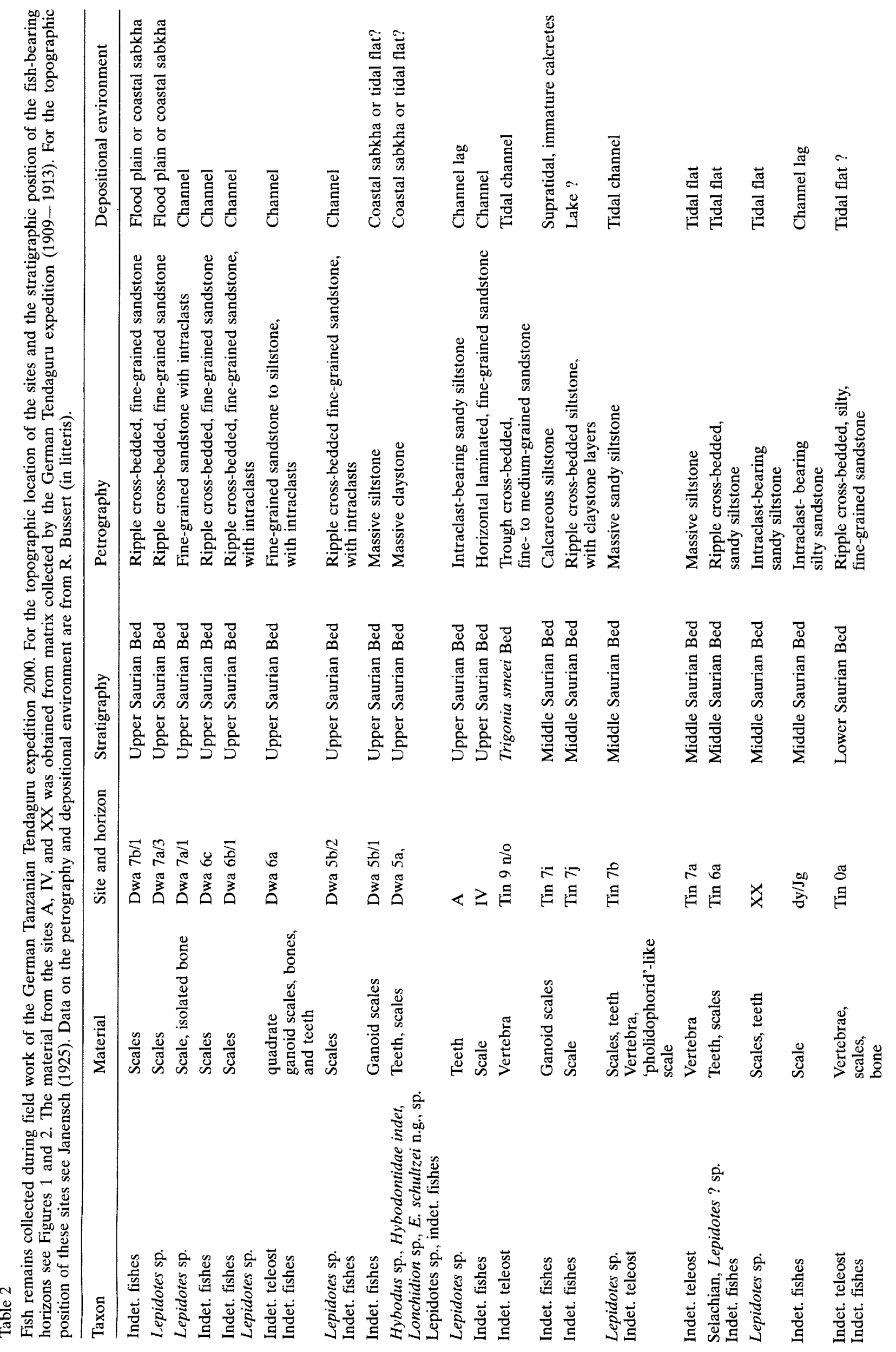


Late Jurassic fishes from Tendaguru, Tanzania were described and figured by Hennig (1914a) and more recently by Arratia \& Schultze (1999). Hennig (1914a) identified a selachian as Orthacodus sp. from the Upper Saurian Bed and actinopterygian remains as Lepidotes minor (Lepidotes cf. minor in the explanation of plate 23). The actinopterygian was subsequently referred to Lepidotes tendaguruensis (Arratia \& Schultze 1999). New material obtained from the site of Dwa 5a in 2000 contains the first records of hybodonts and batoids from the Late Jurassic (Kimmeridgian-Tithonian) of east Africa. This assemblage differs distinctly in its taxonomic composition from that of the Mugher Mudstone Formation in Ethiopia.

\section{Systematic Paleontology}

Class Chondrichthyes Huxley, 1880

Subclass Elasmobranchii Bonaparte, 1838

Cohort Euselachii Hay, 1902

Superfamily Hybodontoidea Zangerl, 1981

Family Hybodontidae Owen, 1846

Genus Hybodus Agassiz, 1837

Type species: Hybodus reticulatus Agassiz, 1837 from the Sinemurian, Lower Jurassic of Lyme Regis, South England.

\section{Hybodus sp.}

Fig. 3A-H

Material: An isolated tooth crown lacking the lateral crown portions and the root (MB. f.7731) and a fragmentary lateral tooth portion (MB. f.7732), Dwa 5a sample 6.

Description: Specimen MB. f.7731 is an isolated and abraded asymmetrical cusp. The lateral portions and the root are lacking. The apex shows strong wear patterns. The cusp is approximately $2.0 \mathrm{~mm}$ high, massive, triangular in outline, and broad at its base. In profile, the cusp is moderately bent lingually. The cutting edges are prominent and continuous without serrations. The labial face is rather flat with eight vertical and non-bifurcating enameloid ridges. One ridge is broken. The labial ridges do not reach the base of the tooth crown but reach far apically. The ridges do not attain to the cusp apex but seem to be restricted to the basal $85 \%$ of the cusp. Additional short vertical ridges intervene between the longer, coarser ridges. The lingual face is only slightly more convex than the labial face. There are seven vertical ridges that are confined mainly to the lateral portions of the cusp leaving the central area of the cusp almost smooth. They are shorter compared to those on the labial face and end well above the crown base.

The second specimen (MB. f.7732), which may be attributed to this species of Hybodus, is a lateral fragment of a tooth crown exposing two lateral cusplets. No remains of the root are present. The first preserved cusplet is high and labiolingually compressed with an acute apex. The second is much lower with a rounded apex and a convex lateral margin in labial view. The first cusplet exposes three long, well-developed, and non-bifurcating vertical ridges on its labial face. The ridges neither reach the apex nor the base of the cusplet. Two additional faint and short vertical ridges occur on the distal portion of the larger cusp. The ornamentation of the lingual face is very similar with five strong vertical ridges. The ridges end well above the base of the cusplet. The cutting edge is strong and continuous between the two lateral cusplets in occlusal view. There are no indications of serrations along the cutting edges and no vertical ridges between the two cusplets. The outermost cusplet is rectangular to pyramidal in occlusal view. A single, slightly curved ridge is present on its labial face, whereas there are two on the lingual face. One of the lingual ridges curves and meets the distal most ridge of the larger cusplet. The mesial portion is platform-like and enlarged in occlusal view, indicating the likely presence of a lingual shelf.

Discussion: The status of Hybodus and closely related forms such as Egertonodus and Polyacrodus is presently unclear. Maisey (1987) established Egertonodus for Hybodus basanus from the Lower Cretaceous of England based on skeletal characters. He also referred Hybodus fraasi to Egertonodus and interpreted this group as more advanced than Hybodus. However, the type species of Hybodus, $H$. reticulatus, from the Sinemurian of South England shares many similarities in tooth morphology with $E$. basanus. Conversely, Hybodus hauffianus from the Toarcian of southeastern Germany is similar in skeletal morphology with $H$. reticulatus but differs strongly in tooth morphology from both $H$. reticulatus and $E$. basanus. The teeth of $H$. hauffianus are characterized by a small protuberance on the basal part of the lingual face of the main cusp, which is keel-like in some teeth and over- 


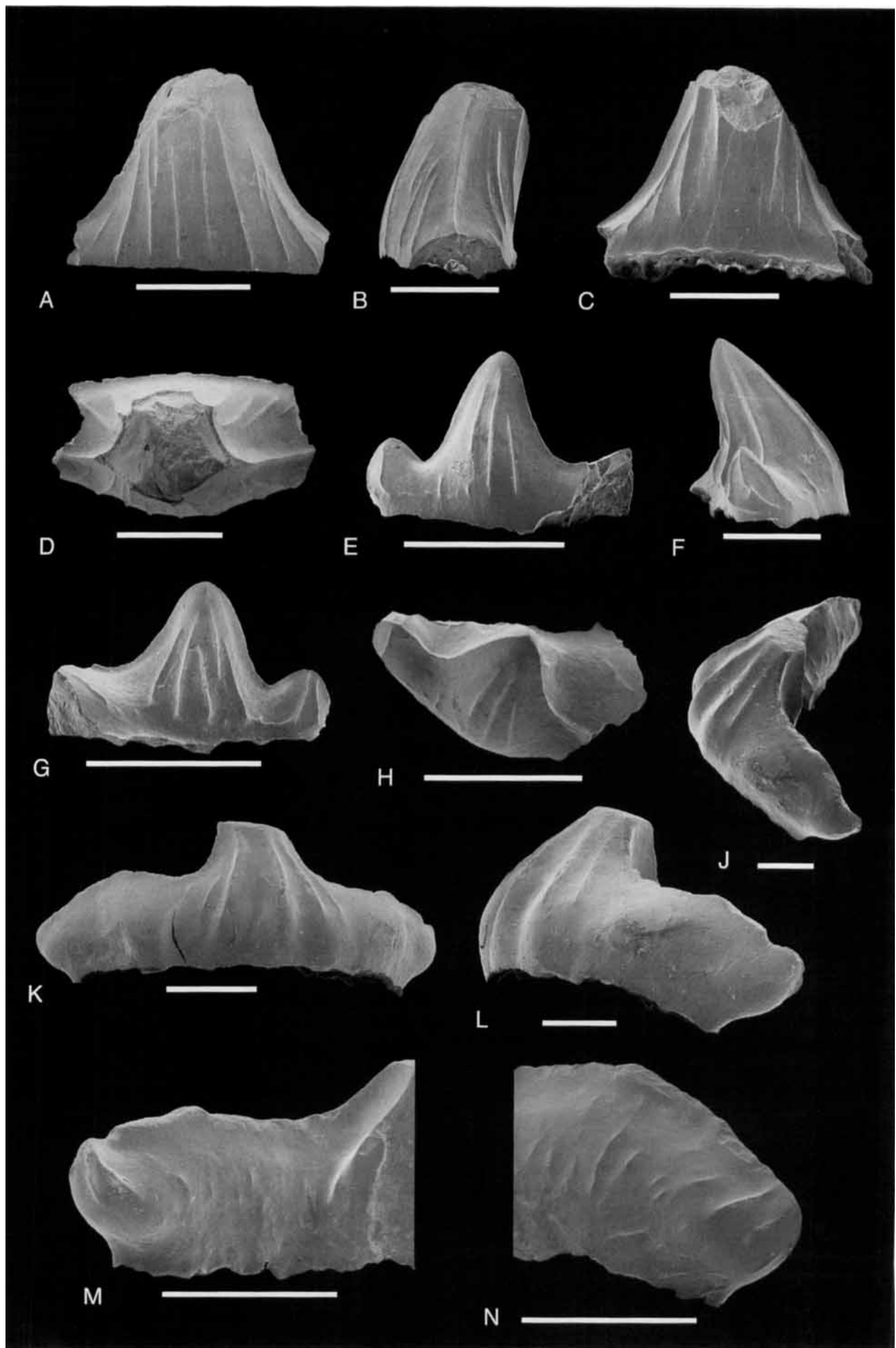


hangs the root to some degree and the basal labial nodes (Duffin 1997, JK pers. obser.). In this protuberance, teeth of Hybodus hauffianus resemble those of Hybodus parvidens from the Lower Cretaceous of England. H. parvidens was assigned to Polyacrodus by several authors (e.g., Cappetta 1987). Moreover, Hybodus has been used traditionally as a "wastebasket" for species with similar tooth morphologies and is still poorly defined. In fact, there is no valid definition of Hybodus teeth available at the moment. Woodward (1916) was the last who included distinct tooth characters in the definition of $\mathrm{Hybo}$ dus. Maisey (1987) included "multicuspid acuminate teeth with osteodont crowns" in the diagnosis of Hybodus. However, these characters are not very helpful since multicuspid and acuminate teeth are present in a wide range of neoselachian and hybodont sharks. In addition, Maisey (1987) also uses the character "multicuspid osteodont teeth" in the diagnosis of Egertonodus. Both Hybodus and Egertonodus form a group possessing teeth adapted for tearing and holding. This is in contrast to a second group of hybodonts with durophagous dental morphology (e.g., Acrodus, 'Polyacrodus'). The differentiation of Hybodus teeth from those of Egertonodus is very difficult were it not for numerous materials present to show the variety. Teeth of $H$. reticulatus have a symmetrical main cusp with an enlarged base in some tooth positions (lateral?), whereas teeth of Egertonodus basanus are always asymmetrical with the main cusp being sigmoidally twisted in anterior positions and distally bent in lateral to posterior positions. This character is difficult to use when distinguishing Egertonodus teeth. A revision of both genera based on tooth morphologies will provide additional information.

Specimen MB. f.7731 resembles teeth of Hybodus reticulatus to some extent in the overall form and ornamentation. However, differences are found in that occasionally single ridges are divided to form two closely parallel ridges. Vertical ridges are generally unbroken in Hybodus reticulatus. The Tendaguru specimen differs from $\mathrm{Hy}$ bodus hauffianus and Hybodus parvidens in the absence of basal nodes and a labial keel. The absence of bifurcating ridges distinguishes it from teeth of $H$. cloacinus Quenstedt, 1885 from the Rhaetian and Sinemurian? and Egertonodus basanus. The teeth of Hybodus ensis from the Lower Cretaceous of England and of Hybodus songaensis Saint-Seine \& Casier, 1962 from the Middle Jurassic of the Congo are characterized by large and massive teeth with weak and generally very short vertical ridges, contrary to the condition found in the Tendaguru specimens. The Ethiopian specimens certainly do not relate to Hybodus.

The lateral tooth fragment from Tendaguru indicates a shelf along the lingual tooth crown base, which is also found occasionally in teeth of Hybodus reticulatus but not in Egertonodus basanus. However, more and better-preserved material is necessary to identify the Tendaguru hybodont specifically.

The specimen from Tendaguru is easily differentiated from teeth of Priohybodus in that the former lacks distinct and serrated cutting edges. It can be distinguished from Ethiopian specimens by its general morphology and moderately developed and rather distinct ornamentation. In addition, there are no striations on the occlusal crest intervening with the coarse striations of the cusp in the Tendaguru specimens.

\section{Hybodontidae indet.}

Fig. 3J-N

Material: MB. f.7733: A single isolated tooth crown lacking the root, Dwa 5a sample 6.

Description: The single specimen (MB. f.7733) is an isolated tooth crown with preserved lateral portions but lacking the root. The strong curvature indicates an anterior position of the tooth within the dentition. The tooth crown is mesiodistally elongated and approximately 3 times wider than high. The central cusp is very low but well detached from the crown base and moderately bent distally. The apex is abraded. The cutting edge is prominent and continuous between the main cusp and the lateral crown shoulders in occlusal view. There are several vertical enameloid ridges running downwards from

Fig. 3. Hybodonts from site Dwa 5a. A-D. Hybodus sp., specimen MB. f.7731. A. Labial view. B. Lateral view. C. Lingual view. D. Occlusal view. E-H. Hybodus sp., specimen MB f7732. E. Labial view. F. Lateral view. G. Lingual view. H. Occlusal view. J-N. Hybodontidae indet. MB. f.7733. J. Occlusal view. K. Labial view. L. Lateral view. M. Close up of mesial crown portion, lingual view. $\mathbf{N}$. Close up of distal crown portion, lingual view. Scale bars $=1.0 \mathrm{~mm}$. 
the abraded area of the apex. They do not reach the base of the crown. The crown shoulders are very high in labial view. The main cusp is approximately 1.7 times higher than the lateral crown shoulders. The distal cutting edge is convex in labial view and bears three very low and faint lateral cusplets mesially. The most proximal cusplet forms the outermost edge of the cusp and is robust. The base of the crown is incized. The labial face of the distal and mesial crown shoulders is completely smooth and convex in profile. The lingual face of the main cusp is damaged exposing the dentine. Some vertical ridges extend from the abraded apex downwards without reaching the base of the crown. The ornamentation of the lateral crown shoulders consists of numerous fine, short, vertical ridges arranged randomly. They are mainly confined to the lower-central portions. Two stronger ridges are present on the mesial portion. They start from the transverse cutting edge and stop well before the base of the crown. The tooth crown is curved in occlusal view with the lateral tips being lingually inclined.

Discussion: The single tooth obtained from Dwa 5a undoubtly belongs to a hybodont shark. However, the absence of well-defined lateral and acuminate cusplets differentiates this specimen from Hybodus, Egertonodus, and Polyacrodus. With its labiolingually compressed and rather high crown in labial view, weak and very low lateral cusplets on the mesial heel, it resembles teeth of Lonchidion. It is distinguished from the teeth of Lonchidion and from the more robust, low-crowned teeth of Lissodus in the absence of a well marked labial protuberance (labial peg). The presence of keel-like labial ridges resembles the condition found in teeth of Hybodus parvidens. However, teeth of Hybodus parvidens have a considerably lower crown with well-developed lateral cusplets and generally only a single strong labial keel. Rees \& Underwood (in press) erect a new genus for teeth described as Lissodus rugianus from the Early Cretaceous of Germany by Ansorge (1990) based on the character combination "minute teeth with main cusp and lateral cusplets, lower and more elongated lateral teeth, well developed rounded labial protuberance, which is often supported by root buttress". Specimen MB. f.7733 differs from teeth of this genus in the absence of both lateral cusplets and a labial protuberance. Nevertheless, the minute teeth and presence of lateral cusplets may not be diagnostic characters. Thurmond (1971) de- scribed teeth from the Aptian and Albian of Texas as Hybodus butleri that are characterized by rather large teeth with only poorly developed lateral cusplets and a rounded labial protuberance that is occasionally supported by a root buttress. Therefore $H$. butleri may belong to the new genus described by Rees \& Underwood (in press). The character combination of the Tendaguru specimen described above separates it from all known hybodonts and indicates the presence of a hitherto unknown hybodont genus in the Late Jurassic. However, it is not practical to base a new taxon on a single tooth crown.

Records of Late Jurassic hybodonts from Africa include teeth of the rare selachian Priohybodus arambourgi (e.g., Duffin 2001a), Hybodus spp. similar to $H$. grossiconus and $H$. ensis, as well as other unidentified species (d'Erasmo 1960), and the peculiar crushing teeth reported from Ethiopia (Goodwin et al. 1999). The new hybodont from Tendaguru can easily be distinguished from teeth of Priohybodus in the absence of distinct and serrated cutting edges and from the Ethiopian specimens by its general morphology and the moderately developed and rather distinct ornamentation. In addition, there are no striations on the occlusal crest intervening with the coarse striations of the cusp in the Tendaguru specimens.

Family Lonchidiidae Herman, 1977
Genus Lonchidion Estes, 1964

\section{Lonchidion sp.}

Fig. 4

Material: MB. f.7734: A single isolated tooth crown lacking the root, Dwa 5a sample 6.

Description: The single specimen is an isolated tooth crown with a low profile. The central main cusp is obtuse, low, stout, and slightly inclined distally. The apex is strongly abraded. The cusp is laterally flanked by minute, poorly developed lateral cusplets. These are more prominent on the distal crown portion. The cutting edge of the mesial portion of the crown is undulating and rises to three vestigial cusplets. The outermost cusplets are rounded in labial and lingual views and form the mesial and distal edges of the crown respectively. In occlusal view, the cutting edge is continuous between the main cusp and the lateral cusplets and is more or less straight. The labial protuberance is not pronounced and overhangs the basal portion of the crown only 


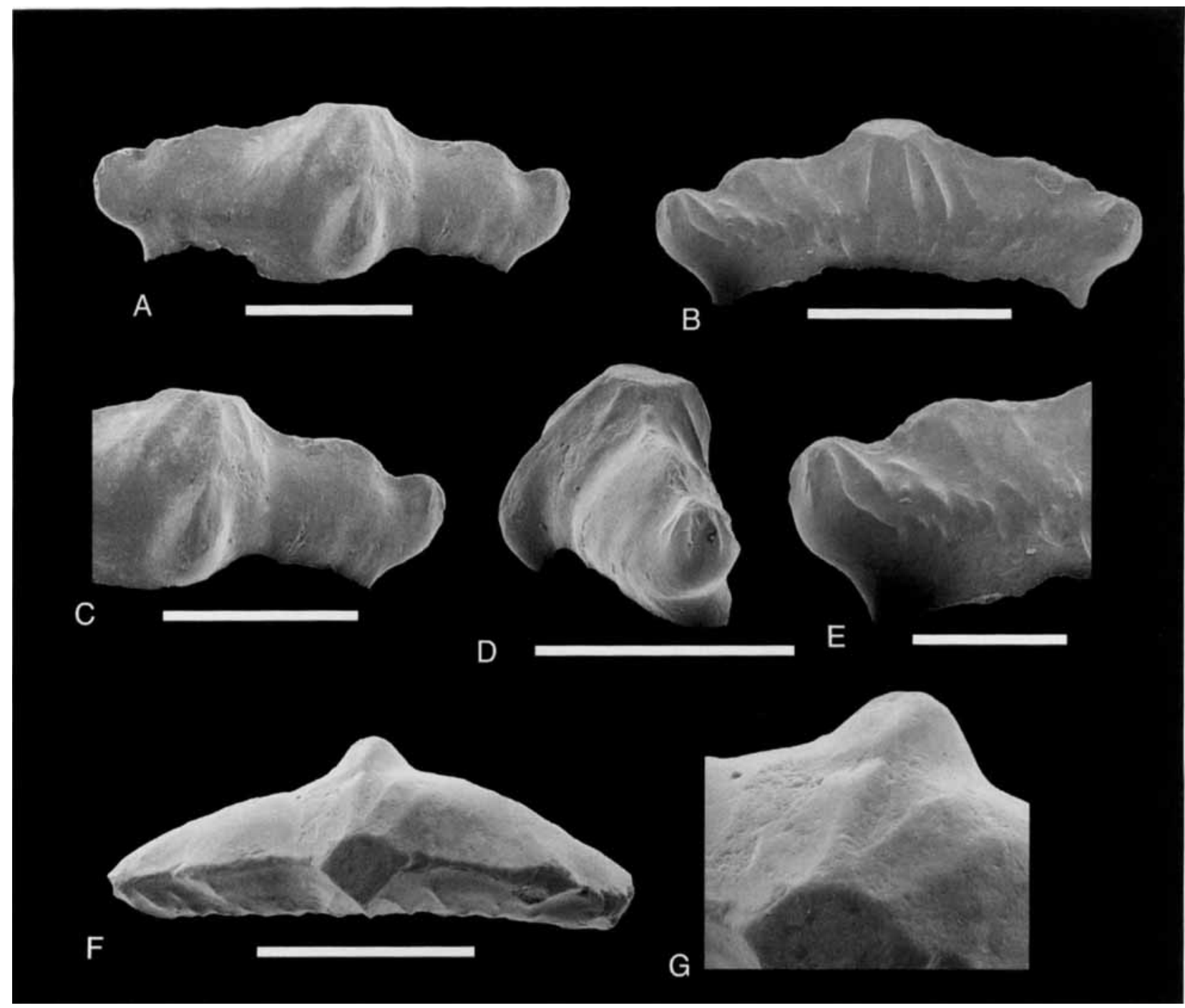

Fig. 4. Lonchidion sp. MB. f.7734. A. Labial view. B. Lingual view. C. Close up of labial peg and distal cusplets, labial view. D. Lateral view. E. Close up of distal crown portion, lingual view. Scale bat $=0.5 \mathrm{~mm}$. F. Occlusal view. G. Close up of labial peg, occlusal view. Scale bars $=1.0 \mathrm{~mm}$.

slightly in profile view. The lateral margins of the protuberance are sub-parallel in labial view. The labial ornamentation consists of few vertical ridges that are confined to the main cusp. The lateral portions of the labial crown face are smooth. There is a vertical ridge on the upper portion of the protuberance ascending the central cusp as is found in several other species. Three additional weak vertical ridges are present extending downward from the apex of the main cusp. The lingual face is characterized by numerous, short vertical ridges along the crown shoulder and additional nodes near the base of the crown shoulder, giving it a crenulated appearance.

Discussion: The single tooth crown MB. f.7743 is attributed to Lonchidion. This genus was erected by Estes (1964) but was subsequently synonymized with Lissodus Brough,
1935 by Duffin (1985) who presented a list of characters to justify the inclusion of all Lonchidion species within Lissodus. Main characters for identification of Lissodus are a low crown profile and the presence of a labial protuberance (labial peg) of the tooth crown that is not supported by the root. In a review, Duffin (2001b) defends this interpretation and indicates the presence of 38 species and 26 further, still not specifically identified members of Lissodus. However, these characters are found occasionally also in several other hybodonts (Acrodus, 'Polyacrodus', Hybodus parvidens) and the genus Lissodus sensu Duffin $(1985,2001 b)$ contains a variety of different tooth types. Maisey (1990) argued for the synonymy of Lonchidion with Lissodus, however, Rees $(1998,1999)$ stated that Duffin's genus Lissodus is not monophyletic. Subsequently, Rees \& Underwood (in press) differentiate Lissodus and 
Lonchidion providing emended diagnoses for both. In addition, they introduce two new genera based on isolated teeth that were attributed to Lissodus by Duffin (1985).

The character combination found in the single tooth from Tendaguru is characteristic for teeth of Lonchidion. The specimen differs significantly from all other known species especially in the ornamentation of the lingual crown face. It resembles teeth of $L$. crenulatum Patterson, 1966 from the Wealden of southern England. However, the crenulations are developed on the labial face in the Wealden species, whereas they are restricted to the lingual face in the Tendaguru specimen. A specific attribution of the Tendaguru specimen is not justified since the material consists only of a single tooth.

The genus Lonchidion is wide spread in the Mesozoic of Europe and North America. In Africa it is so far known only from the Early Cretaceous of Morocco (Duffin \& SigogneauRussell 1993). The Tendaguru specimen is the first record of this taxon in the Late Jurassic of the southern hemisphere and represents the oldest evidence of Lonchidion in Africa. The oldest African representative of the closely allied genus Lissodus, L. africanus (Broom 1909), comes from the Upper Beaufort Series of the Orange Free State in southern Africa, which is upper Scythian in age (Hutchinson 1973).

Subcohort Neoselachii Compagno, 1977

Superorder Squalomorphii Compagno, 1973

Order Synechodontiformes Duffin \& Ward, 1993

Family Orthacodontidae Glikman, 1957

Genus Sphenodus Agassiz, 1843

\section{Sphenodus sp.}

Fig. 5

Synonym: 1914a Orthacodus sp. Hennig: 304, pl. 23, figs $2 \mathrm{a}-\mathrm{c}$.

Material: MB. f.7728, two isolated tooth crowns. MB. f7729, one isolated tooth crown. MB. i.4 one thin section (Hennig 1914a: pl. 23, fig. 2c). All teeth were recovered from the base of the Upper Saurian Bed exposed at Tendaguru Site Om ("Graben Om").

Description: The tooth crowns are tall and measure up to $1.5 \mathrm{~cm}$ in height and $0.65 \mathrm{~cm}$ wide at the base. They are rather slender, and pointed. All are bent lingually and have a slightly sigmoidal mesial view. The cutting edges are well developed and not serrated. Laterally, they are extended by heels that are all damaged in the Tendaguru specimens, which are lacking the outermost portions. The labial face is only moderately convex with short, vertical ridges at its base. The lingual face is strongly convex with fewer but longer enameloid ridges that are sometimes subdivided into shorter ones. The root is lacking from all specimens.

Discussion: Hennig (1914a) described four isolated tooth crowns, which were recovered from the base of the Upper Saurian Bed in the "Om Graben", and attributed them to Orthacodus Woodward, 1889 (= Sphenodus Agassiz, 1843). Sphenodus includes many ill-defined species ranging from the Liassic, Early Jurassic to the Danian, early Palaeocene (Cappetta 1987). A list of species attributed to Sphenodus is presented by Duffin \& Ward (1993: 58). A discussion of the authorship of the family Orthacodontidae can be found in Böttcher \& Duffin (2000). Teeth of this genus are rather common in Jurassic deposits of Europe (e.g., de Beaumont 1960). There are three valid species of Sphenodus pre-

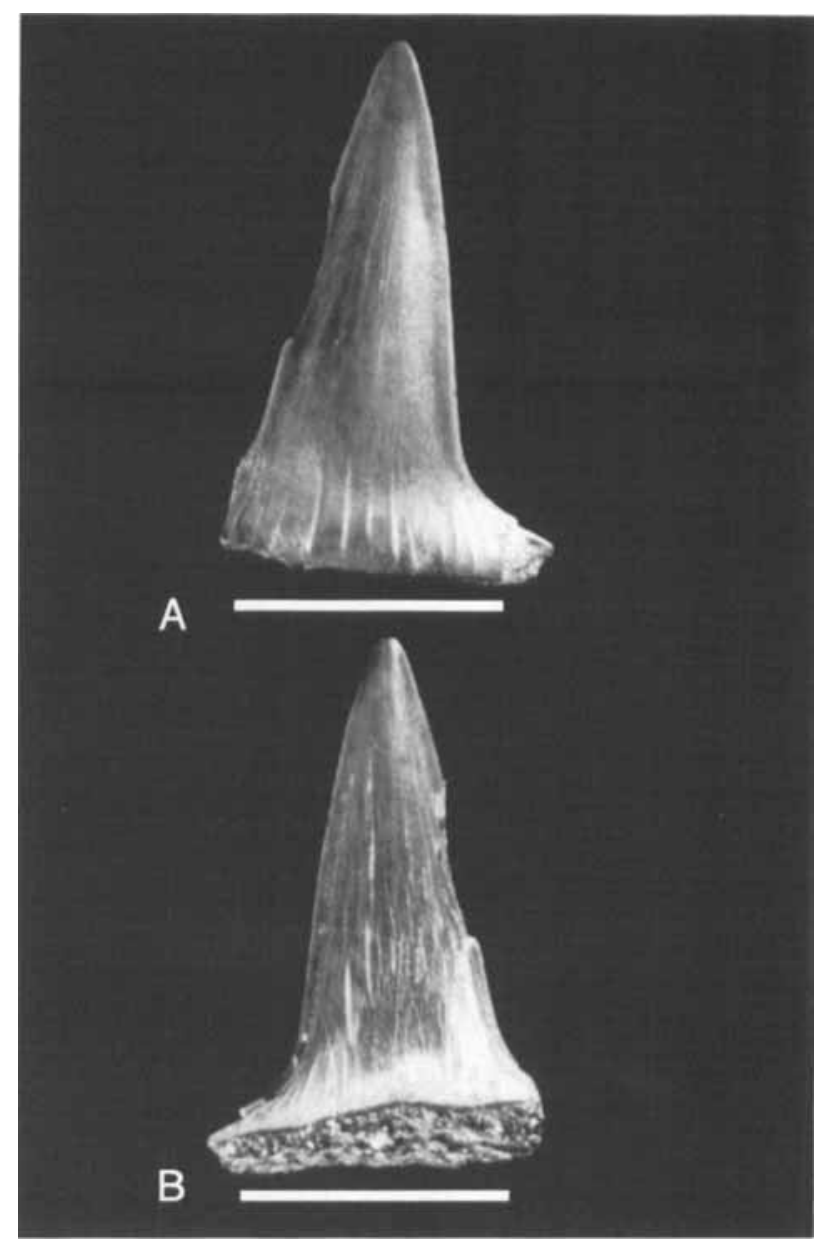

Fig. 5. Sphenodus sp. MB. f.7729. A. Labial view. B. Lingual view. Scale bars $=0.5 \mathrm{~cm}$. 
sent in the Late Jurassic of Germany (Böttcher \& Duffin 2000). These represent the best-known species to date. $S$. macer (Quenstedt, 1851) is known by completely articulated skeletons from the upper Kimmeridgian of Nusplingen. Isolated teeth attributed to this species also occur in the middle Oxfordian to lower Kimmeridgian of southern Germany (Duffin 1993, Böttcher \& Duffin 2000). A partial skeleton from the lower Tithonian of the Solnhofen Plattenkalke was described as $S$. nitidus by Wagner (1862). This species also occurs in the upper Oxfordian and lower Kimmeridgian of southern Germany (Duffin 1993) and in the upper Kimmeridgian of the Nusplingen Plattenkalke (Böttcher \& Duffin 2000). The type-species of Sphenodus, S. longidens Agassiz, 1843, has a rather long stratigraphic range from the Early Jurassic to the early Kimmeridgian (Böttcher \& Duffin 2000) and is known from many localities through Europe. Other species assigned to Sphenodus are recorded from Late Jurassic deposits of France, Austria, Russia, Carpathians of Central Europe, and Sicily (de Beaumont 1960).

Teeth of Orthacanthus (= Sphenodus) also were reported from the Late Jurassic Lugh Series of Somalia by d'Erasmo (1960). Some fragmentary teeth resemble those of $O$. longidens Agassiz, 1843 and $O$. virgai Gemmellaro, 1868. However, none of the figured specimens (d'Erasmo 1960: figs 13, 19, 20) allow any specific identification because of their fragmentary preservation. The Tendaguru specimens differ in the broader tooth crown especially at the base where the cutting edges continue onto the lateral heels. However, these features may be related to tooth position and may not be specific differences.

The specimens of Sphenodus from Tendaguru confirm the presence of this taxon in the Southern Hemisphere during the Late Jurassic and extend the occurrence of Sphenodus further southward. Unfortunately, the fragmentary preservation of the teeth and the unsatisfactory state of our knowledge concerning valid species to be included in Sphenodus, does not allow specific identification. Hennig (1914a) interpreted Sphenodus as scavenger since the teeth occur together with disarticulated remains of theropods, teeth of crocodilians, and other unidentified bone fragments.

Superorder Batomorphii Cappetta, 1980

Order Rajiformes Berg, 1940

Suborder Rhinobatoidea Fowler, 1941

Rhinobatoidea incertae sedis

\section{Genus Engaibatis nov.}

Diagnosis: Rajiform batoid characterized by very small teeth, less than $1 \mathrm{~mm}$ in width. Dentition heterodont. All teeth asymmetrical. Crownroot junction not incized. Neck collar broad and lingually overhung by the uvula. Anterior teeth with a pair of low and blunt lateral cusplets. Cusplets reduced laterally. Teeth longer than wide in anterior to anterolateral position, wider than long in more lateral positions. Labial contour rounded and labially projected over the root. No protuberance or apron. Labial visor not very broad or flat. Tooth crown ornamentation confined to the inside of the labial visor and labial part of the neck collar. Transverse crest sharp. Central cusp low, pointed, and distally displaced. Lateral heels of crown convex in anterior and anterolateral rows, mesial heel continuous with apex and distal heel convex in lateral teeth. Lingual face not very steep or abrupt. Central uvula massive and more or less long with abrupt and steep club-like posterior edge in anterolateral teeth. Lateral uvulae absent. Root massive, wide, and displaced lingually. Labial face vertical and straight, only slightly higher than the lingual face. Root lobes oblique and laterally protruding from the crown. Lobes narrow and V-shaped. Groove lingually narrow with posterior notch, labially wide. Lingual opening of notch displaced below the median uvula in anterior teeth. One to two pairs of marginolingual foramina. Central foramen wide and placed posteriorly in groove.

Etymology: Derived from the name of the Masai god Engai and from the Greek word batis meaning ray.

Type species: Engaibatis schultzei n. sp.

Age: Late Jurassic, Late Kimmeridgian-Tithonian.

\section{Engaibatis schultzei n. sp.}

Figs $6 \mathrm{~A}-\mathrm{P}, 7 \mathrm{~A}-\mathrm{F}$

Diagnosis: Same as for genus.

Holotype: Isolated tooth MB. f.7735, Dwa 5a, sample 6 .

Paratypes: Two isolated teeth, Dwa 5a samples 2 (MB. f.7736) and 6 (MB. f.7737).

Type locality: Dwa 5a, Dwanika stream section north-northeast of Tendaguru Hill, southern Tanzania.

Type horizon and age: Lowermost part of section Dwa 5 (samples 2 and 6), Upper Saurian 

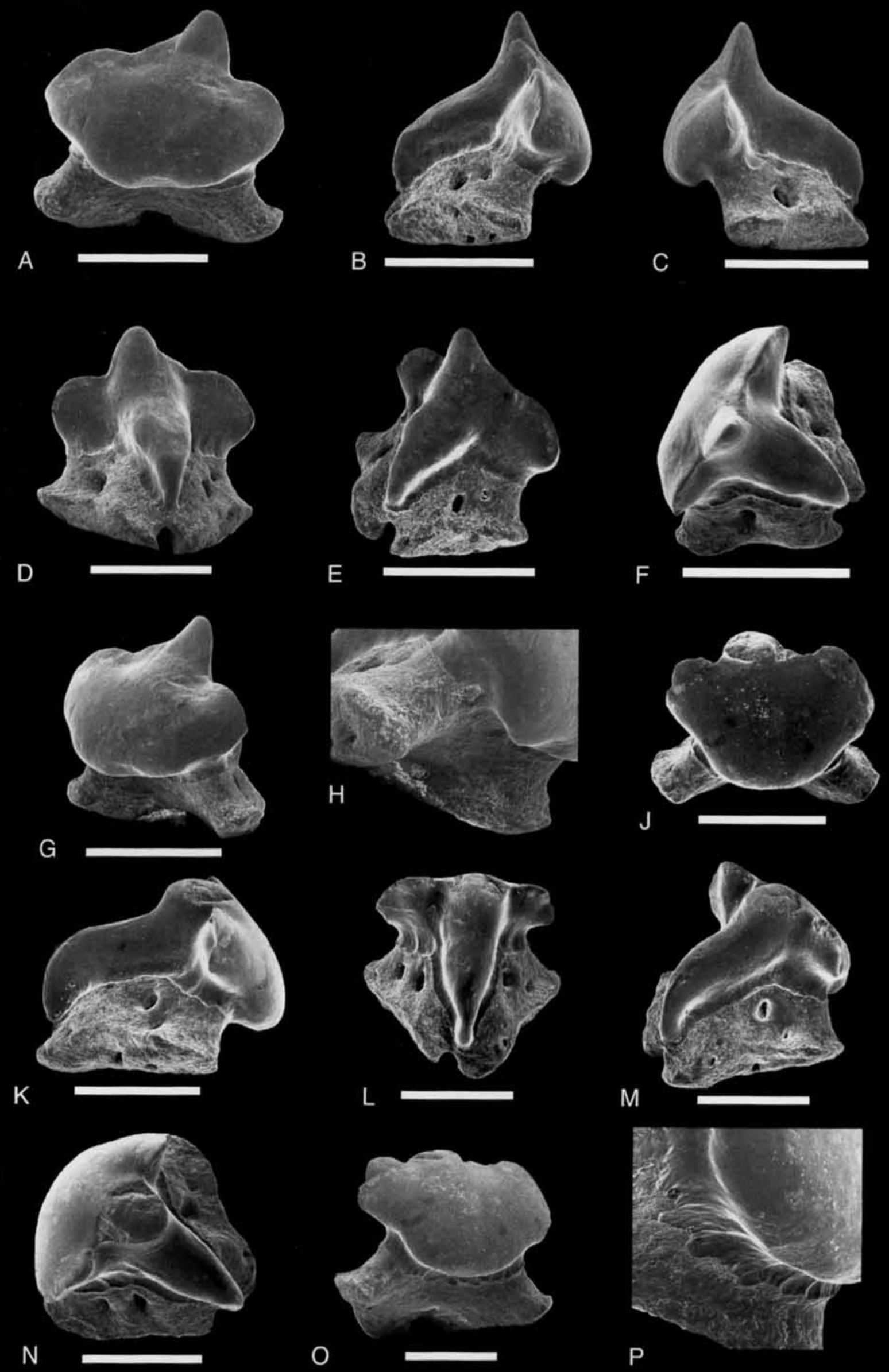
Bed, Late Jurassic, Late Kimmeridgian-Tithonian.

Etymology: In honor of Hans-Peter Schultze who has strongly supported the Tendaguru research projects of the Institut für Paläontologie of the Humboldt Universität zu Berlin.

Description: The dentition of this species is characterized by very small and asymmetrical teeth, less than $1 \mathrm{~mm}$ in width. Rather strong probably gradient heterodonty is present. What are probably anterior to anterolateral teeth (Dwa 5a, sample 6) are longer labiolingually than they are wide mesiodistally. The crown is mesiodistally elongated. The contour of the labial face is rounded in labial view. The transverse crest is sharp and more or less straight in occlusal view. It reaches the lateral angles of the crown and rises centrally into a low central cusp, which is slightly bent distolingually. The apex is pointed and rather narrow in profile. The lateral heels are convex forming a pair of very low and blunt cusplets. The distal margin of the tooth crown of paratype MB. f.7737 is notched in labial view. The profile of the labial face is slightly concave below the cusp. The basal margin is broadly rounded and overhangs the root. There is no defined protuberance or apron. The inside of the labial visor is flat and exhibits a characteristic ornamentation. The visor is directed ventrally in profile. The lingual face is shallow and abrupt. There is a well-developed central uvula. Lateral uvulae are absent. The central uvula is straight, very long and narrow. The posterior edge is club-like in the paratype MB. f.7736 (Fig. 6L). In lateral view the uvula is rather high with a more or less posteriad oblique occlusal surface. The posterior part of the uvula is very abrupt and steep in profile view. The crown-root junction is not incized but there is a broad neck collar that is almost completely overhung by the uvula posteriorly.

The root is massive, wide, and displaced lingually. The labial face is vertical and straight in profile and is only slightly higher than the lingual face. The root lobes protrude lateral to the crown with oblique basal faces in labial view. In basal view, the root lobes are labiolingually elongate but mesiodistally narrow and more or less oval in outline. The surfaces are moderately convex. The lobes are in an arranged V-shape. Lingually, the posterior portions of the lobes form a narrow groove. This groove open lingually into a medium-sized notch, which is displaced below the median uvula. Labially, the groove is wide open and concave in labial view. A rather large central foramen opens posteriorly into the notch of the root lobes. The holotype exhibits two marginolingual foramina on the mesial side and a single one on the distal side. The paratype from Dwa 5a, sample 6 has a pair of marginolingual foramina on each side of the root. Smaller, additional foramina open on the surfaces of the root lobes.

Teeth of a more lateral or even posterior position (paratype Dwa 5a, sample 2, MB. f.7737) are also asymmetrical and characterized by a rather triangular contour of the labial face. The crown is almost as long labiolingually as it is wide mesiodistally. The labial face is almost straight in profile view and juts out above the root. The basal margin of the labial face is moderately concave. The visor's edge is horizontal and almost straight in profile view. The transverse crest is sharp and straight in occlusal view. It rises centrally into a pointed cusp, which is not well offset from the crown. The mesial cutting edge is continuous and there is only a small, cusp-like structure at the greatest width of the crown. The distal cutting edge between apex and crown also is continuous but notched forming a low and rounded distal heel. The median uvula is massive and short with a rounded posterior edge.

The morphology of the root corresponds in its general appearance to that described above. The labial face is rather high and almost as high as the lingual face. The lobes are asymmetrical in labial view forming the characteristic basin like structure that is enclosed by the labially open lobes and narrows posteriorly to a distinct groove. One or two marginolingual foramina are present.

Fig. 6. Engaibatis schultzei n. gen. and n. sp. A-H. Holotype MB. f.7735, Dwa 5a, sample 6. A. Labial view. B. Mesial view, showing pair of marginolingual foramina. C. Distal view, showing single marginolingual foramen. D. Lingual view. E. Linguomarginal view. F. Occlusal view. G. Marginolabial view. H. Close up of characteristic ornamentation on inside of labial visor. J-P. Paratype MB. f.7736, Dwa 5a, sample 6. J. Labial view. K. Distal view. L. Lingual view. M. Linguomarginal view. N. Occlusal view. O. Labiobasal view exposing morphology of root. P. Close up of characteristic ornamentation. Scale bars $=0.5 \mathrm{~mm}$. 


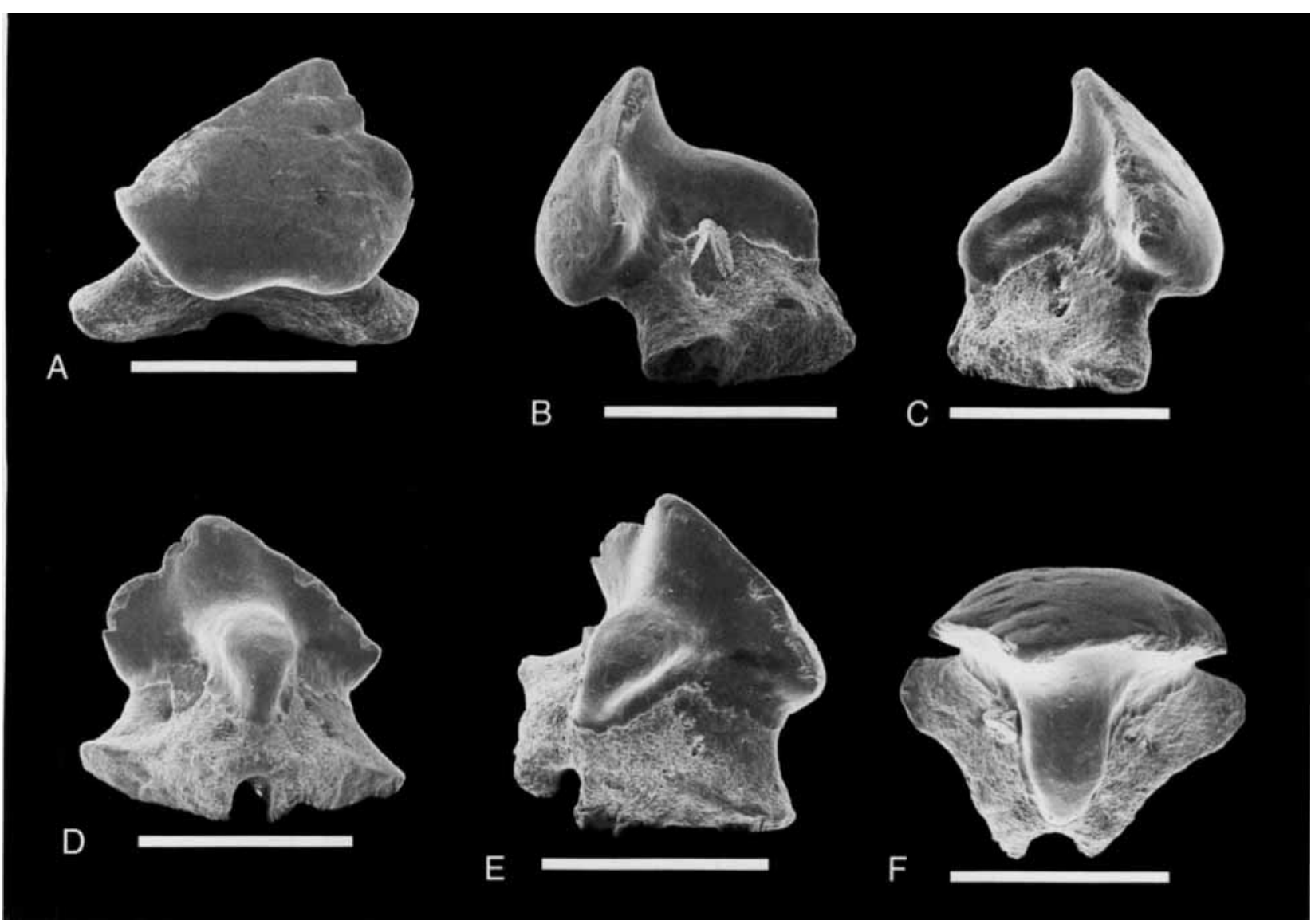

Fig. 7. Engaibatis schultzei n. gen. and n. sp., paratype MB. f.7737, Dwa 5a, sample 2. A. Labial view. B. Distal view. C. Mesial view. D. Lingual view. E. Linguomarginal view. F. Occlusal view. Scale bars $=0.5 \mathrm{~mm}$.

The crowns of all teeth are smooth with the exception of a folded sculpture on the inside of the labial visor. This sculpture is restricted to the labial part of the neck collar. The neck collar is distinct in all teeth but is covered lingually by the uvula. Anterior teeth are characterised by a pair of low, blunt lateral cusplets, which are reduced laterally. The root is of the holaulacorhize type with a characteristic morphology that resembles that found in several rajids. The roots of the teeth in E. schultzei n. gen. and n. sp. are asymmetrical.

Discussion: Jurassic batoids are known mainly from Europe. The only specimen that consists of more than isolated teeth from the Southern Hemisphere comes from middle Tithonian sediments of Argentina (Cione 1999). The Jurassic species are attributed to the families Rhinobatidae Müller \& Henle, 1838 and Archaeobatidae Delsate \& Candoni, 2001. Archaeobatids include the genera Toarcibatis, Cristabatis, and Doliobatis that are only known from the Toarcian of Belgium, Luxembourg, and northern France (Delsate \& Candoni 2001). Teeth of these genera are easily distinguished from the Tanzanian taxon in the morphology and ornamentation of the tooth crowns and especially in the morphology of the root, which is described as pre-rhinobatoid and similar to the sclerorhynchid type by Delsate \& Candoni (2001).

Rhinobatids are represented mainly by teeth generally identified as Spathobatis and Belemnobatis (Thies 1983, Cavin et al. 1995, Delsate \& Candoni 2001, Underwood \& Ward in press). The oldest representative occurs in the Toarcian and Aalenian of northern Germany (Spathobatis? moorbergensis Thies, $1983=B e$ lemnobatis? moorbergensis Cavin et al., 1995) and Toarcian of France (aff. Belemnobatis cf. moorbergensis, Delsate \& Candoni 2001). Middle Jurassic batoids include several species of both Belemnobatis and Spathobatis, which persist into the Tithonian (Thies 1983, Cavin et al. 1995). In addition, a third batoid, Asterodermus occurs in the lower Tithonian of southern Germany (e.g., Leidner \& Thies 1999). Cavin et al. (1995) presented an identification key of teeth of Belemnobatis and Spathobatis and provided 
several tooth crown characters for differentiation. Nevertheless, the identification of isolated teeth remains difficult.

The batoids Asterodermus and Spathobatis are similar in that they possess long rostra and in placoid scale morphology (Leidner \& Thies 1999). These features distinguish both genera from Belemnobatis. But the teeth of Asterodermus more closely resemble the teeth of Belemnobatis sismondae in having mesiodistally expanded crowns with a rudimentary central cusp and a more or less entire convex labial visor without distinct medial protuberance (Leidner \& Thies 1999). A prominent median cusp and an apron distinguish the teeth of Spathobatis bugesiacus from teeth of Asterodermus.

Underwood \& Rees (in press), apparently unaware of the paper by Leidner \& Thies (1999) and without having investigated original material, consider Asterodermus a nomen dubium. However, the dental and placoid scale morphologies found in Late Jurassic batoids (e.g., Cavin et al. 1995, Leidner \& Thies 1999, JK pers. obser.) suggest that all three genera are valid. In addition, the teeth from the Purbeckian of England ascribed to Belemnobatis by Underwood \& Rees (in press) must be placed within another batoid genus along with the Early Cretaceous species attributed to Spathobatis (e.g., Biddle 1993, Kriwet 1999).

The teeth of Engaibatis schultzei n. gen. and n. sp. share several similarities with teeth of $A s$ terodermus, Belemnobatis, and Spathobatis, mainly in the morphology of the crown. The unique combination of crown characters indicated in the generic diagnosis (e.g., asymmetrical tooth crown, presence of low lateral cusplets in antero-lateral teeth, the absence of a labial protuberance, the very well-developed and long median uvula, which overhangs the neck collar lingually, and the crenulated lower visor's face) in combination with the unique root morphology, which is probably asymmetrical in all tooth positions and is more similar to that found in several rajiids than in typical rhinobatids, distinguishes the teeth of Engaibatis n. gen. easily from teeth of Asterodermus, Belemnobatis, Spathobatis, and all other known batoids. Engaibatis n. gen. is left here within Rajiformes as family incertae sedis because the systematics and phylogenetic relationships of Late Jurassic batoids is not yet fully understood.

The new batoid from Tendaguru represents the second and oldest record of Late Jurassic rays from Africa. Whether the species is identi- cal with that from the Tithonian of Ethiopia cannot be ascertained at present.

\section{Class Actinopterygii Cope, 1887}

Actinopterygians are rare in the Upper Jurassic beds of Tendaguru (Tables 1,2) where they are represented by almost complete specimens of Lepidotes tendaguruensis and numerous disarticulated scales and vertebrae (Hennig 1914a, Arratia \& Schultze 1999). Although Hennig (1914a) noted the presence of a pycnodontid and cranial fish remains, the material cannot be checked because it is lost apparently. Among the material recently recovered, there are incompletely preserved and disarticulated actinopterygian fishes that are listed below.

\section{Division Halecostomi Regan, 1923 \\ Order Semionotiformes Arambourg \& Bertin, 1958 \\ Family Semionotidae Woodward, 1890 pro part Genus Lepidotes Agassiz, 1832}

Description and Discussion: Lepidotes tendaguruensis is a fish known from numerous specimens that are generally articulated. The specimens are of moderately small size, reaching about $250 \mathrm{~mm}$ total length; other species of Lepidotes are much larger. Its morphology is rather well known allowing a more or less detailed osteological description based on the partly articulated specimens. Consequently, Arratia \& Schultze (1999) questionably assigned $L$. tendaguruensis to one group of the Semionotidae that includes some species of Lepidotes and Araripelepidotes (sensu Wenz 1999). This assigment is tentative because $L$. tendaguruensis presents a mosaic of morphological features that conflicts its inclusion not only within the Lepidotes-Araripelepidotes group and within Pliodetes, as well as within the remaining species of Lepidotes. To discern the proper taxonomic assignment and the relationships of $L$. tendaguruensis, further material is required as well as an extensive revision of the whole genus Lepidotes.

Material that served as the basis for the description of $L$. tendaguruensis was recovered in Trench XIIa, approximately $700 \mathrm{~m}$ north of Tendaguru Hill, and in locality $\mathrm{M}$, approximately $250 \mathrm{~m}$ south of Tendaguru Hill. Most specimens of $L$. tendaguruensis from these localities are articulated and with the scales in situ. In contrast, the new material includes numerous isolated scales of Lepidotes-type (Table 2). 


\section{Lepidotes sp.}

Fig. 8A

Material examined: MB. f.7723 a complete, isolated scale. MB. f.7724, isolated scale. MB. f.7725, isolated scale; and numerous incomplete scales.

Description and Discussion: Isolated scales assigned to Lepidotus sp. were mentioned by Hennig (1914a). It is uncertain as to whether those scales belong to Lepidotes tendaguruensis because the poor scale preservation of the type and paratype specimens. In addition, the scales studied by Hennig have worn surfaces or are incomplete. The new material reported here (e.g., Fig. 8A) can be confidently included within the semionotiforms and interpreted as Lepidotes. Lepidotes is a cosmopolitan genus represented by numerous poorly described species all over the world; consequently, it is almost impossible to make comparison with scales of other species.

Division Halecomorphi Patterson, 1973

Teleosteomorpha sensu Arratia, 2001

Teleosteomorpha incertae sedis

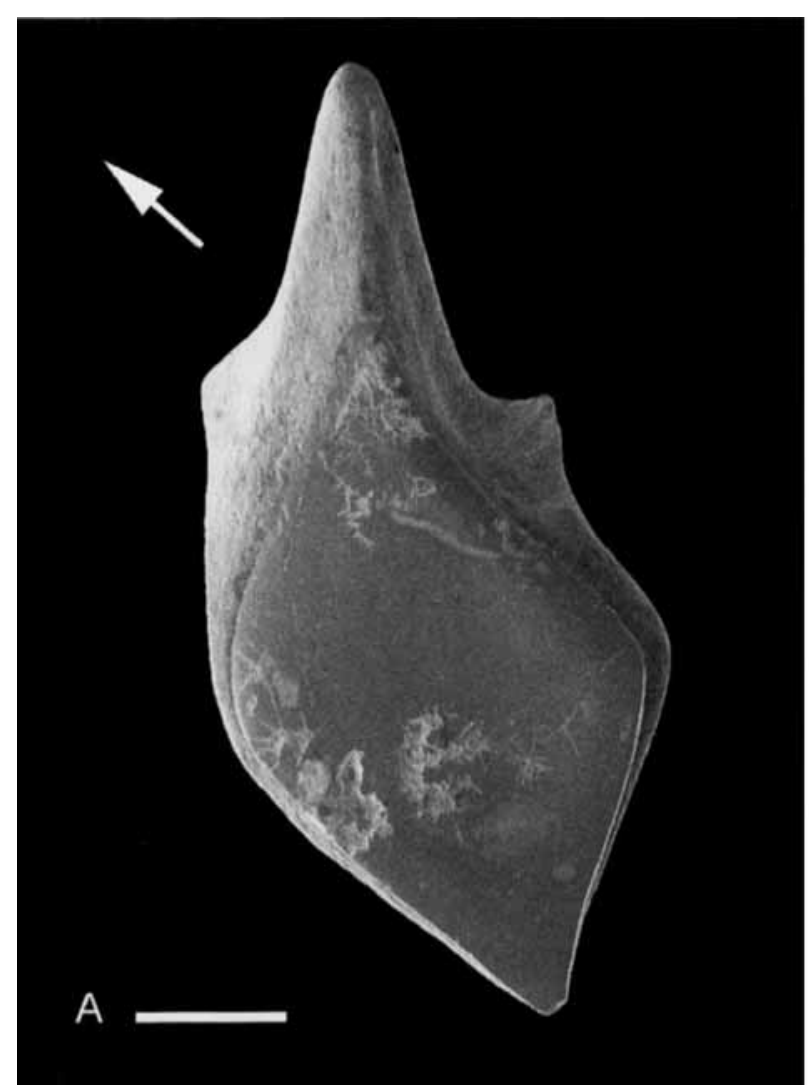

\section{'Pholidophoriform'-like fishes}

Fig. 8B

Material examined: MB. f.7726, isolated scale. MB. f.7748 (SEM), isolated scale.

Description and Discussion: Among the isolated scales from locality Dwa 6c, there are ganoid scales that show similarities to those of certain 'pholidophoriforms' (sensu Arratia 2000a). The scales (Fig. 8B) are rectangularly-shaped, deeper than long, and have a moderately sharp peg dorsally. No ornamentation is observed on their surface and their posterior margin is smooth.

Similar scales are known from different ages and localities in the world. For example, they are present in Triassic members of the genus Pholidophorus from Austria and Italy (Schultze 1966, Arratia pers. obser. on P. latisculus) and in the Late Jurassic (Kimmeridgian) Siemensichthys siemensis from southern Germany (Arratia 2000a). Similar scales are also present in other 'pholidophoriforms' such as pleuropholids.

A few pleuropholids have been recorded from the Late Jurassic African deposits, first by SaintSeine (1955). Among them, members of the genera Pleuropholis, Parapleuropholis, and Austropleuropholis are known from Stanleyville, Zaire.

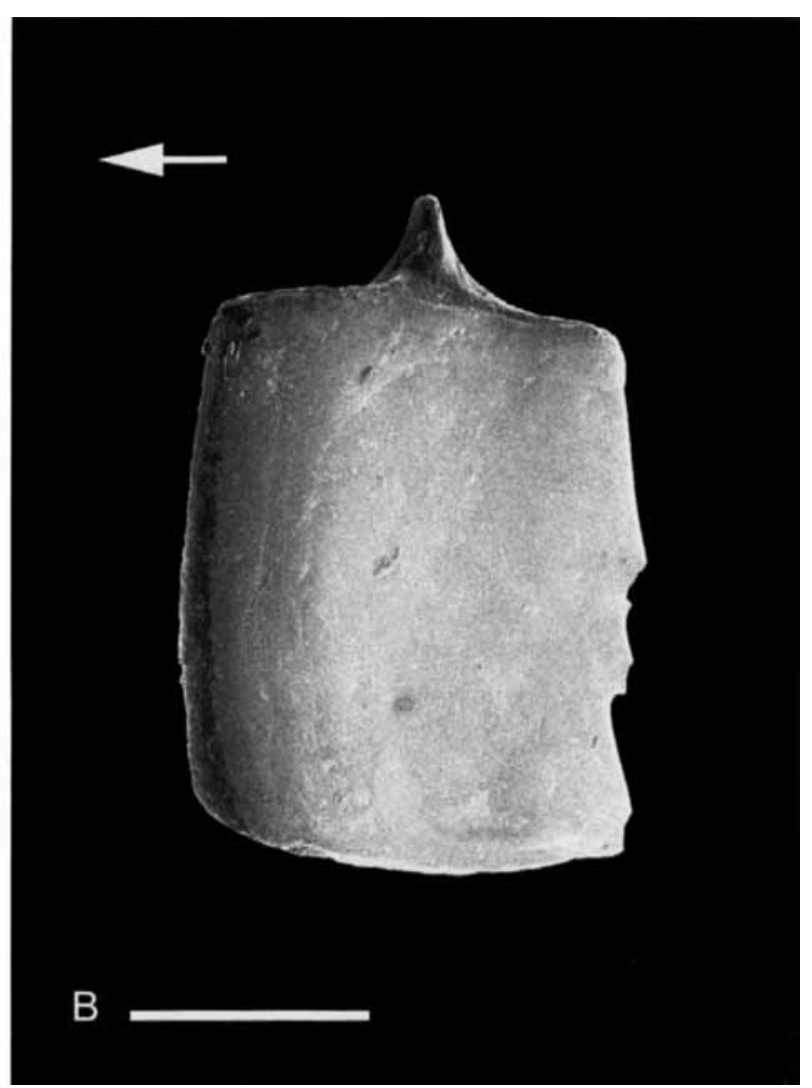

Fig. 8. Scales. A. Lepidotes sp. $(30 \times)$. B. 'Pholidophoriform'-like fish $(35 \times)$. Arrows point anteriorly. 
Due to the incompleteness of the fossil remains and lack of diagnostic characters in the studied material, the scales cannot be assigned to any 'pholidophoriform' or to any pleuropholid taxon. Because the so-called Order Pholidophorifomes is an unnatural assemblage, including numerous genera and species from all over the world, and some of the former members occupy very different positions in cladograms (e.g., Patterson 1977, Arratia 2000a). It is, therefore, impossible to assign the material to any 'pholidophoriform' taxon; thus, the scales are interpreted as belonging to a teleosteomorph incertae sedis.

Class Actinopterygii Cope, 1887

Subdivision Teleostei sensu Arratia, 1999

Teleostei incertae sedis

\section{Undetermined teleost}

Fig. 9A-D

Material: MB. f.7724, addominal vertebrae (two prepared for SEM). MB. f.7726, incomplete vertebra.

Description and Discussion: Among the disarticulated remains (Table 2), there are a few abdominal and at least one incomplete caudal vertebra. The centra are small elements about two $\mathrm{mm}$ in diameter and one and a half $\mathrm{mm}$ long. These vertebrae are supposed to belong to the same taxon because of their identical structure and superficial ornamentation. Due to the size of the vertebrae, the fishes were probably only a few centimeters in total length.

The abdominal vertebrae are represented by two complete and three incomplete centra. The centra are almost circular in diameter, with a small notochordal foramen (Fig. 9C, D) and thick walls. The centra are formed by a thin chordacentrum surrounded by a well ossified, thick autocentrum with cavities for adipose tissue. The dorsal arcocentra are autogenous in the abdominal vertebrae, whereas the ventral arcocentra are fused to the ventrolateral part of the centrum forming the region where the ribs articulate. In contrast, both the dorsal and ventral arcocentra are fully fused to the autocentra in the caudal vertebrae.

Dorsally, the abdominal centra show two elongated cavities (almost as long as the centrum), where left and right halves of the neural arch (or arcocentra) articulate. The two cavities are not well exposed in Figure 9A because the remains of the matrix could not be removed without da- maging the centra. Both articular cavities are separated from each other by a sharp, narrow crest. Due to the distance between both cavities, it is assumed that the neural arch was small and narrow. Laterally, one centrum (Fig. 9B) shows a reticulate pattern of grooves and cavities; however, the other centrum presents several elongated grooves and crests (Fig. 9D) (oriented anterior to posterior) giving a characteristic aspect to the vertebral surface. These grooves and crests are not as numerous and narrow as those in Late Jurassic elopomorphs (e.g., Arratia 1997: text-figs 32,34 ; 2000b: fig.11) or in the ichthyodectiform vertebrae found in the Late Jurassic European genera Pachythrissops and Allothrissops (Arratia 1997: figs 22A, B, 24; 2000b: fig. 9).

The abdominal centra do not bear parapophyses for articulation of the ribs. The ribs articulate on broad ventrolateral cavities (Fig. 9B). Each cavity is surrounded by a thick anterior border that presumably aided (with the help of ligaments) to keep the rib in position.

The structure of the vertebral centra corresponds to that of teleostean fishes, above the level of Leptolepis coryphaenoides, in the cladogram of teleostean phylogenetic relationships proposed by Arratia (1997: fig. 99, 1999: figs 19, 20). Leptolepis coryphaenoides has ring-like abdominal centra whose main element is the ringlike chordacentrum that leaves a large, round notochordal foramen. The autocentrum is represented by a smooth, thin layer of compact bone overlying the chordacentrum (see Schultze \& Arratia 1989, Arratia 1997: fig. 89A-C). The structure of the small vertebrae from Tendaguru is similar to that of other Late Jurassic and those of younger teleosts with reduced chordacentrum, well-developed autocentrum, and cavities for fatty tissue (see Arratia 1991, Arratia \& Schultze 1992, Arratia et al. 2001). However, the notochordal canal is smaller than that in Leptolepis coryphaenoides but slightly larger than that of other Late Jurassic teleosts.

In conclusion, the structure of the vertebrae from Tendaguru can be identified as teleostean vertebrae, belonging to fishes that are placed above the Leptolepis coryphaenoides phylogenetic level. Due to a lack of broadly comparative data on the external morphology of teleostean vertebrae (fossil and Recent), we are unable to give them a taxonomic assignment.

Late Jurassic teleosts from Africa have been reported. Among these taxa, the peculiar genera Catervariolus, Ligulella, and Majokia have been described by Saint-Seine (1955) and later inter- 

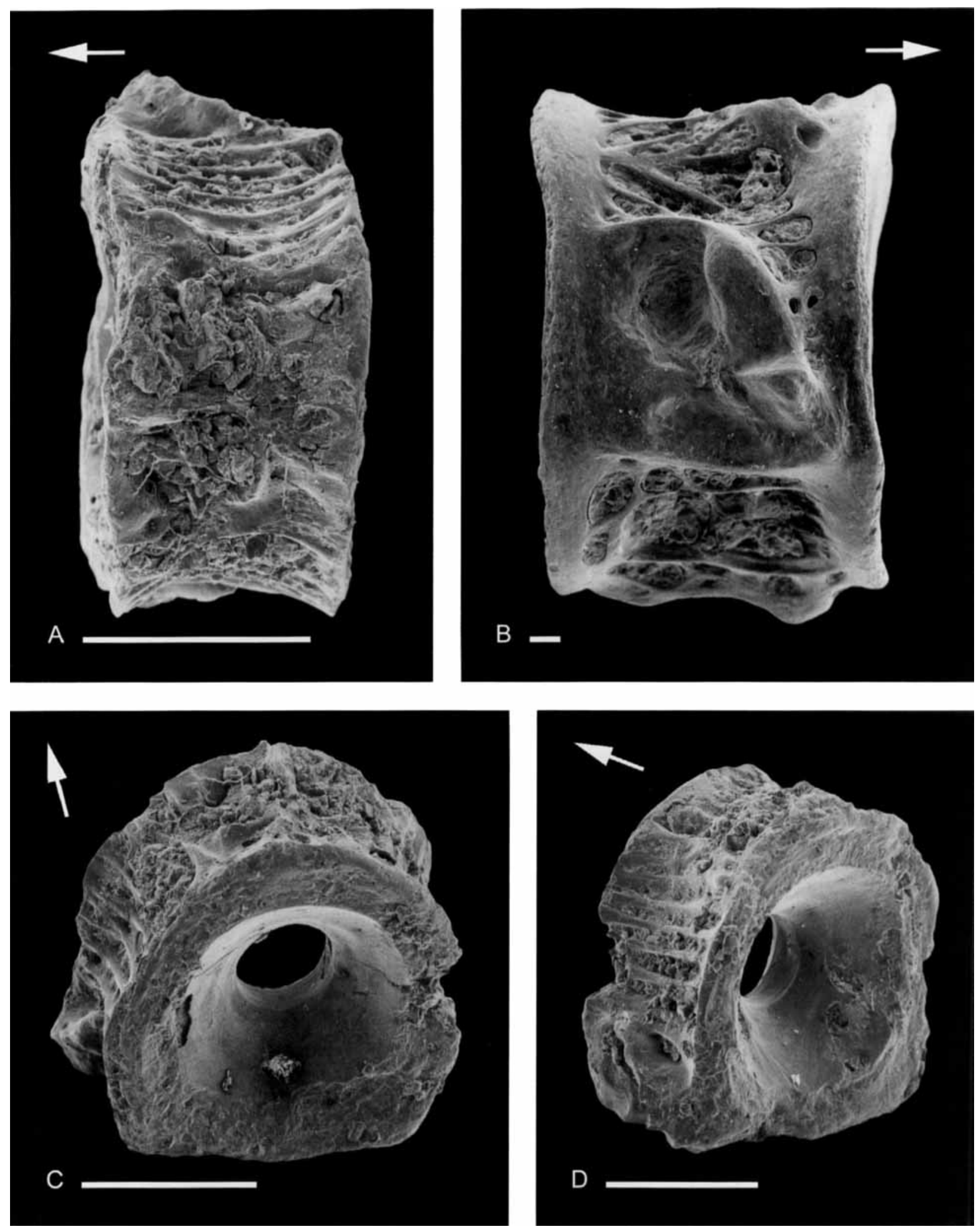

Fig. 9. Teleostean vertebrae. A. Dorsal view of abdominal centrum (MB. f.7734a; 35×). B. Ventrolateral view of an abdominal centrum showing the articular region for a rib (MB. f.7724b; 45x). C. Lateroposterior view of an abdominal centrum showing the thickness of the autocentrum and chordacentrum. Notice the moderately large notochordal foramen (MB. f.7724a; 30×). D. The same abdominal centrum in Fig. C, but turned more laterally to show the ornamentation of the surface $(30 \times)$. Arrows point anteriorly.

preted by Schaeffer \& Patterson (1984) as teleosts incertae sedis. Members of these three genera possess peculiar morphology. The structure of their vertebrae, so far as known, does not correspond to that described and illustrated for the vertebrae recovered in the Tendaguru beds. The 
vertebrae found belong to a new African fish, not yet described, due to incomplete preservation.

\section{Final comments}

During the Late Jurassic and Early Cretaceous, the Gondwana continent was breaking up and the separation of the Laurasian and Gondwana supercontinents resulted from the connection of the Tethys sea with the proto-Atlantic and the Pacific Ocean. In addition, the South Atlantic developed towards the end of the Late Jurassic with the separation of South America and Africa. Africa became increasingly isolated from most other continents by marine barriers from the Kimmeridgian into the Early Cretaceous but retained a continental connection with South America (Smith et al. 1994, Goodwin et al. 1999). Global sea levels dropped significantly in the Early Jurassic and remained low through the Middle Jurassic but rose considerably towards the Late Jurassic, deepening the marine trenches between continents (Haq et al. 1987).

The largest and best known samples of African Late Jurassic terrestrial and coastal vertebrate faunas are those of the Mugher Mudstone Formation (Tithonian) in Ethiopia (Goodwin et al. 1999) and of Tendaguru. Although past collecting at Tendaguru focused on excavations of dinosaurs, the German-Tanzanian expedition in 2000 concentrated on the sedimentological history and the smaller faunal elements. The intensive microvertebrate sampling in dinosaur-bearing matrix collected by the first German expedition and by the German-Tanzanian Tendaguru expedition in 2000 produced new material of selachians with a new ray and actinopterygians including teleostean remains.

Even though the study of these microvertebrates is still in its infancy, the new material contributes much to our understanding of the palaeoenvironment of the Tendaguru depositional area and also closes a gap in our knowledge of Late Jurassic fish distribution. A remarkable feature of site Dwa 5a is the presence of an endemic hybodont-batoid selachian association, thus far unknown from other Jurassic localities. It is similar to one reported from the Mugher Mudstone Formation in Ethiopia in general taxonomic composition. Both faunas are characterized by the dominance of hybodont taxa and the almost complete absence of neoselachian taxa, especially neritic and pelagic forms. This composition can be regarded as indicative of shallow coastal water and near shore faunas. Both hybodonts and neoselachians represent slow swimming, near bottom or bottom dwelling predators.

Accordingly to the present study, the selachian fauna includes five taxa, three of which are new. However, only a new batoid genus is named. Additionally, two isolated teeth, that do not allow a definite specific identification, certainly represent new hybodont taxa. Almost all taxa from Tendaguru are members of cosmopolitan groups. The suprageneric affinities of the new batoid are uncertain due to the unknown status of most Late Jurassic batoids from Europe (e.g., Spathobatis, Belemnobatis). Engaibatis schultzei n. gen. and $n$. sp. belongs, along with batoids from the Tithonian of Ethiopia (Goodwin et al. 1999) and Argentina (Cione 1999), to the oldest known rays from the Southern Hemisphere. The known distribution pattern of Late Jurassic rays in the Northern and Southern Hemisphere indicates that batoids migrated southwards from their place of origin on the Northern Hemisphere (Europe?) early in their evolutionary history. Nevertheless, our knowledge about Jurassic selachian distribution and taxonomy is still in its infancy and the poor fossil record represents certainly a collecting bias.

\section{Acknowledgements}

We are grateful to Dr. R. Bussert (Technische Universität Berlin) for data on the petrography and depositional environment of the fish-bearing strata and G. Maier (Calgary, Canada) for his help with sampling the Tendaguru Beds. Financial support from the Deutsche Forschungsgemeinschaft (He 2757/1-3) is gratefully acknowleged. This research has been supported by a Marie Curie Fellowship of the European Community program "Improving Human Research Potential and the Socio-economic Knowledge Base" under contract number HPMF-CT-2001-01310 to JK. Thanks are also due to B. Reichenbacher (Munich) for allowing JK to examine specimens from the Upper Jurassic of southern Germany for comparison. C. Underwood (London) and D. Thies (Hannover) are greatfully acknowledged for discussions on Late Jurassic selachians. E. Siebert (Museum für Naturkunde, Berlin) kindly improved the illustrations. We are indebted to L. A. Cione (La Plata), J. Chorn (Lawrence, Kansas), and C. Duffin (Surrey), for critically reviewing the manuscript and to $\mathrm{C}$. Chang-Arratia for critically improving the style.

\section{References}

Aberhan, M., Bussert, R., Heinrich, W.-D., Schrank, E., Schultka, St. 2002. Paleoecology and depositional environments of the Tendaguru Beds (Late Jurassic to Early Cretaceous, Tanzania). Mitteilungen aus dem Museum für Naturkunde in Berlin, Geowissenschaftliche Reihe 5: $19-44$. 
Agassiz, L. 1832. Untersuchungen über die fossilen Fische der Lias-Formation. - Jahrbuch für Mineralogie, Geognosie und Petrefaktenkunde 3: 139-149.

- 1833-44. Recherches sur les Poissons Fossiles. 5 vols., 1420 pp., with supplements. Petitpierre, Neuchâtel et Soleure.

Aitken, W. G. 1961. Geology and Palaeontology of the Jurassic and Cretaceous of Southern Tanganyika. - Bulletin of the Geological Survey of Tanganyika 31: $1-144$.

Ansorge, J. 1990. Fischreste (Selachii, Actinopterygii) aus der Wealdentonscholle von Lobber Ort (Münchgut/Rügen/ DDR). - Paläontologische Zeitschrift 64: 133-144.

Arambourg, C. \& Bertin, L. 1958. Super-Ordres des Holostéens et des Halécostomes (Holostei et Halecostomi). In Grassé, P. (ed.). Traité de Zoologie 13 (3): 2173-2203, Masson et Cie., Paris.

Arratia, G. 1991. The caudal skeleton of Jurassic teleosts; a phylogenetic analysis. In Chang, M.-M., Y-Lui, Y.-L. \& Zhang, G. R. (eds). Early Vertebrates and Related Problems in Evolutionary Biology: 249-340 Science Press, Beijing.

- 1997. Basal teleosts and teleostean phylogeny. - Palaeo Ichthyologica 7: 5-168.

- 1999. The monophyly of Teleostei and stem-group teleosts. Consensus and disagreements. In Arratia, G. \& Schultze, H.-P. (eds). Mesozoic Fishes 2 - Systematics and Fossil Record: 265-334, Verlag Dr. F. Pfeil, München.

- 2000a. New teleostean fishes from the Jurassic of Southern Germany and the systematic problems concerning the 'pholidophoriforms'. - Paläontologische Zeitschrift 74 (1/2): $113-143$.

- 2000b. The sister-group of Teleostei: Consensus and disagrements. - Journal of Vertebrate Paleontology 21 (4): $767-773$

- 2001. The sister-group of Teleostei: Consensus and disagreements. - Journal of Vertebrate Paleontology 21 (4): $767-773$.

Arratia, G. \& Schultze, H.-P. 1992. Reevaluation of the caudal skeleton of certain actinopterygians fishes. III. Salmonidae. Homologization of caudal skeletal structures. Journal of Morphology 214: 187-249.

- 1999. Semionotiform fish from the Upper Jurassic of Tendaguru (Tanzania). - Mitteilungen aus dem Museum für Naturkunde in Berlin, Geowissenschaftliche Reihe 4: 135-153.

Arratia, G., Schultze, H.-P. \& Casciotta, J. 2001. Vertebral colum and associated elements in dipnoans and comparison with other fishes: Development and homology. Journal of Morphology 250: 101-172.

- 1999. Semionotiform Fish from the Upper Jurassic of Tendaguru (Tanzania). - Mitteilungen aus dem Museum für Naturkunde Berlin, Geowissenschaftliche Reihe 2: 135-153.

Beaumont, G. de 1960. Contribution à l'étude des genres $O r$ thacodus Woodw. et Notidanus Cuv. (Selachii). - Mémoires suisses de Paléontologie 77: 1-46.

Berg, L. S. 1940. Sistema ryb. - Trudy Zoological Institute, Academy Nauk SSSR (2) : 517 pp. (In Russian.)

Biddle, J.-P. 1993. Les élasmobranches de l'Albien inférieur et moyen (Crétacé inférieur) de la Marne et de la Haute Marne (France). - Belgian Geological Survey Professional Paper 264: 191-240.

Bonaparte, C. L. J. L. 1838. Selachorum tabula analytica. Nuov. Ann. Sci. Natur. 2 (1): 195-214.

Böttcher, R. \& Duffin, C. J. 2001. The neoselachian shark Sphenodus from the Late Kimmeridgian (Late Jurassic) of Nusplingen and Egesheim (Baden-Württemberg, Germany). - Stuttgarter Beiträge zur Naturkunde, Serie B (Geologie und Paläontologie) 283: 1-31.

Broom, R. 1909. Fossils fishes of the Upper Karroo Beds of South Africa. - Annals of South African Museum 7 (3): 251-269.

Brough, J, 1935. On the structure and relationships of the hybodont sharks. - Memoirs and Proceedings of the Manchester Literary \& Philosophical Society (Manchester Memoirs) 79: 35-49.
Bussert, R. 2001. Die flachmarine und koninentale Sedimentation an einer durch Gezeiten, Stürme und Tsunamis(?) geprägten Küste eines passiven Kontinentalrandes (Oberjura-Unterkreide, Südost-Tansania). - Schriftenreihe der Deutschen Geologischen Gesellschaft 13: 28-29.

Cappetta, H. 1987. Chondrichthyes II - Mesozoic and Cenozoic Elasmobranchii. In Schultze, H.-P. (ed.). Handbook of Paleoichthyology, vol. 3B: 193 pp., Gustav Fischer Verlag, Stuttgart, New York.

- 1980. Les sélaciens du Crétacé supérieur du Liban. II. Batoides. - Palaeontographica A 168: 149-229.

Cavin, L., Cappetta, H. \& Séret, B. 1995. Révision de Belemnobatis morinicus (Sauvage, 1873) du Portlandien du Boulonnais (Pas-de-Calais, France). Comparaison avec quelques Rhinobatidae Jurassique. - Geologica et Palaeontologica 29: 245-267.

Cione, A. L. 1999. First report of a Jurassic ray outside of Europe. In Arratia, G. \& Schultze, H.-P. (eds). Mesozoic Fishes 2 - Systematics and Fossil Record, 29-40, München: Verlag Dr. Friedrich Pfeil.

Colin, J.-P. 1994. Mesozoic-Cenozoic lacustrine sediments of the Zaire Interior Basin. In Gierlowski-Kordeschand E. \& Kelt, K. (eds). Global Geological Record of Lake Basins, I. G. C. P. Project 324, 1: 31-36, Cambridge University Press, Cambridge.

Compagno, L. J. V. 1973. Interrelationships of living elasmobranchs. In Greenwwod, P. H., Miles, R. S. \& Patterson, C. (eds). Interrelationships of Fishes. - Journal of Linnean Society 53, Supplement 1: 15-61.

1977. Phyletic relationships of living sharks and rays. American Zoologists 17: 303-322.

Cope, E. D. 1887. Geology and paleontology. - American Naturalist 21: $1014-1019$.

D'Erasmo, G. 1931. Avanzi di pesci della 'Serie di Lugh' in Somalia. - Palaeontographica Italica 32: 29-34.

- 1960. Nuovi avanzi ittiolitici della "serie di Lugh" in Somalia conservati nel Museo Geologico di Firenze. - Palaeontographica Italica LV: 1-23.

Delsate, D. \& Candoni, L. 2001. Description de nouveaux morphotypes dentaires de Batomorphii toarciens (Jurassique inférieur) du Bassin de Paris: Archaeobatidae nov. fam. - Bulletin de la Société naturelle de Luxembourg 102: $131-143$.

Duffin, C. J. 1985. Revision of the hybodont selachian genus Lissodus Brough (1935). - Palaeontographica Abt. A 188: $105-152$.

1993. New records of Late Jurassic shark teeth from southern Germany. - Stuttgarter Beiträge zur Naturkunde, Serie B (Geologie und Paläontologie) 193: 1-13.

- 1997. The dentition of Hybodus hauffianus Fraas, 1895 (Toarcian, Early Jurassic). - Stuttgarter Beiträge zur Naturkunde, Serie B (Geologie und Paläontologie) 256: $1-22$.

- 2001. The hybodont shark, Priohybodus d'Erasmo, 1960 (Early Cretaceous, northern Africa). - Zoological Journal of the Linnean Society 133: 303-308.

- 2001b. Synopsis of the selachian genus Lissodus Brough, 1935. - Neues Jahrbuch für Geologie und Paläontologie, Abhandlungen 221: 145-218.

Duffin, C. J. \& Sigogneau-Russel, D. 1993. Fossil shark teeth from the Early Cretaceous of Anoual, Morocco. - Belgian Geological Survey Professional Paper 264: 175-190.

Duffin, C. J. \& Ward, D. J. 1993. The Early Jurassic Palaeospinacid sharks of Lyme Regis, southern England. - Belgian Geological Survey Professional Paper 264: 53-102.

Estes, R. 1964. Fossil vertebrates from the Lance Formation. - University of California Publications in Geological Sciences 49: 1-187.

Fowler H. W. 1941. The fishes of the groups Elasmobranchii, Holocephali, Isospondyli, and Ostariophysi obtained by US Bureau of Fishing Steamer Albatros. "Bulletin of the U.S. National Museum 100: 1-879. 
Gaudant, J. R. M. \& Stranik, Z. 1972. Leptolepis (poisson teleostéen) dans le Toarcien de la Dorsale Tunisienne. Notes du Service Géologique Tunisien 38: 5-19.

Gemmellaro, G. G. 1868. Studii paleontologici sulla fauna del calcare a Terebratula janitor del nord di Sicilia. Parte I. 18 pp., Palermo.

Glickman, L. S. 1957. On the relationships betwwen the families Lamnidae and Odontaspidae and on new lamnid genera from the Late Cretaceous. - Akad. Nauk SSSR. Tr. Geol Muzeja "A. P. Karpinskogo" 1: 110-117.

Goodwin, M. B., Clemens, W. A., Hutchison, J. H., Wood, C. B., Zavada, M. S., Kemp, A., Duffin, C. J. \& Schaff, C. R. 1999. Mesozoic continental vertebrates with associated palynostratigraphic dates from the northwestern Ethiopian Plateau. - Journal of Vertebrate Paleontology 19: $728-741$.

Haq, B. U., Hardenbol, J. \& Vail, P. R. 1987. Chronology of fluctuating sea levels since the Triassic. - Science 235: $1156-1167$.

Hay, O. P. 1902. Bibliography and catalogue of the fossil Vertebrata of North America. - Bulletin, United States Geological Survey 179: 1-868.

Heinrich, W.-D., Bussert, R., Aberhan, M., Hampe, O., Kapilima S., Schrank, E., Schultka, St., Maier, G., Msaky, E., Sames, B. \& Chami, R. 2001. The German-Tanzanian Tendaguru Expedition 2000. - Mitteilungen aus dem Museum für Naturkunde in Berlin, Geowissenschaftliche Reihe 4: 223-237.

Hennig, E. 1913a. Über neuere Funde fossiler Fische aus Aequatorial- und Südafrika und ihre palaeogeographische Bedeutung. - Sitzungsberichte der Gesellschaft naturforschender Freunde zu Berlin 7: 305-318.

1913b. Mesozoische Wirbeltierfunde in Adamaua. - Beiträge zur geologischen Erforschung der Deutschen Schutzgebiete 7: $10-29$.

- 1914a. Die Fischreste unter den Funden der TendaguruExpedition. - Archiv für Biontologie 3: 293-312.

- 1914b. Beiträge zur Geologie und Stratigraphie Deutsch-Ostafrikas. - I. Geologisch-stratigraphische Beobachtungen im Küstengebiete des südlichen DeutschOstafrika. II. Geologisch-stratigraphische Beobachtungen im Gebiet der Jura-Ablagerungen an der Deutsch-ostafrikanischen Zentralbahn. - Archiv für Biontologie 3: $1-72$.

Herman, J. 1977. Les Sélaciens des terrains néocrétacés et paléocènes de Belgique et des contrées limitrophes. Eléments d'une biostratigraphie intercontinentale. - Mémoires pour servir à l'explication des cartes géologiques et minières de la Belgique: $1-350$.

Hutchinson, P. 1973. A revision of the redfieldiiform and perleidiform fishes from the Triassic of Bekker's Kraal (South Africa) and Brookvale (New South Wales). Bulletin of the British Museum (Natural History), Geology 22: $233-354$.

Huxley, T. H. 1880 . On the application of the laws of evolution to the arrangement of the Vertebrata and more particularly of the Mammalia. - Proceedings of the Zoological Society of London 1880: 649-662.

Janensch, W. 1914. Die Gliederung der Tendaguru-Schichten im Tendaguru-Gebiet und die Entstehung der Saurier-Lagerstätten. - Archiv für Biontologie 3 (3): 227-261.

- 1925. Die Grabungsstellen der Tendaguru-Gegend. - Palaeontographica, Supplement VII (1. Reihe, Teil 1, Lieferung 1): XVII-XIX.

Kriwet, J. 1999. Neoselachier (Pisces, Elasmobranchii) aus der Unterkreide (unteres Barremium) von Galve und Alcaine (Spanien, Provinz Teruel). - Palaeo Ichthyologica 9: $113-142$.

Leidner, A. \& Thies, D. 1999. Placoid scales and oral teeth of Late Jurassic elasmobranchs from Europe. In Arratia, G. \& Schultze, H.-P. (eds). Mesozoic Fishes 2 - Systematics and Fossil Record, 29-40, München: Verlag Dr. Friedrich Pfeil.
MacFadyen, W. A. 1933. The Geology of British Somaliland. - Government of the Somaliland Protectorate, Geology and Palaeontology of British Somaliland 1: 1-87.

Maisey, J. G. 1987. Cranial anatomy of the Lower Jurassic shark Hybodus reticulatus (Chondrichthyes: Elasmobranchii), with comments on hybodontid systematics. - American Museum Novitates 2878: 1-39.

- 1990. Selachii. In Antunes, M. T., Maisey. J. G., Marques, M. M., Schaeffer, B. \& Thomson, K. S. (eds). Triassic fishes from the Cassange Depression (R. P. de Angola). - Ciências da Terra (UNL), Número Especial: $1-64$.

Müller, J. \& Henle, F. G. J. 1838. On the generic characters of cartilaginous fishes, with descriptions of new genera. - Annals and Magazin of Natural History 2: 33-7, 88-91.

Murray. A. M. 2000. The Paleozoic, Mesozoic and Early Cenozoic fishes of Africa. - Fish and Fisheries 1: 111-145.

Oelofsen, B. W. 1981. The fossil record of the class Chondrichthyes in southern Africa. - Palaeontologica Africana 24: 11-13.

Owen, R. 1846. Lectures on the comparative anatomy and physiology of the vertebrate animals, delivered at the Royal College of Surgeons of England in 1844 and 1846. Part 1. Fishes. 308 pp., Longman, London.

Patterson, C. 1966. British Wealden sharks. - Bulletin of the British Museum of Natural History, Geology 11 (7): 283-250.

- 1973. Interrelationships of holosteans. In Greenwood, P. H., Miles, R. S. \& Patterson, C. (eds). Interrelationships of Fishes. - Zoological Journal of the Linnean Society 53, Supplement 1: 233-305. Academic Press, London.

- 1977. The contribution of paleontology to teleostean phylogeny. In Hecht, P. C., Goody, M. K. \& Hecht, B. M. (eds). Major Patterns in Vertebrate Evolution: 579-643. Plenum Press, New York.

Quenstedt, F. A. 1851-1952. Handbuch der Petrefaktenkunde. 792 pp., Laub, Tübingen.

- 1885. Handbuch der Petrefaktenkunde. $3^{\text {rd }}$ ed. 1239 pp, 100 pls. (Atlas). Tübingen.

Rees, J. 1998. Ealy Jurassic selachians from the Hasle Formation on Bornholm, Denmark. - Acta Palaeontologica Polonica 43: 439-452.

- 1999. Late Cretaceous hybodont sharks from the Kristianstad Basin, southern Sweden. - Neues Jahrbuch für Geologie und Paläontologie, Monatshefte 1999: 257-270.

Rees, J. \& Underwood, C. In press. The status of the shark genus Lissodus Brough, 1935 and the position of nominal Lissodus species within Hybodontoidea (Selachii). Journal of Vertebrate Paleontology.

Regan, C. T. 1923. The skeleton of Lepidosteus, with remarks on the origin and evolution of the lower neopterygian fishes. - Proceedings of the Zoological Society of London 1923: 445-461.

Russell, D., Béland, P. \& McIntosh, J. S. 1980. Paleoecology of the dinosaurs of Tendaguru (Tanzania). - Mémoirs de la Société Geologique de France, N. S. 139: 169-175.

Saint-Seine, P. de 1955. Poissons fossiles de l'etage de Stanleyville (Congo belge). - Annales du Musée Royal du Congo belge, Tervuren, Série 8 , Sciences géologiques 14: i-xix $+1-126$

Saint-Seine, P. de \& Casier, E. 1962. Poissons fossiles des couches de Stanleyville (Congo). Deuxième Partie - La faune marine des calcaires de Songa. - Annals du Musée Royal de l'Afrique Centrale, Tervuren, Série 8, Sciences géologiques 44: vii-xi $+1-52$.

Schaeffer, B. \& Patterson, C. 1984. Jurassic Fishes from the Western United States, with Comments on Jurassic Fish Distribution. - American Museum Novitates 2796: 1-86.

Schmidt, D. \& Werner, C. 1998. Early Cretaceous coastal plain sediments of the Mugher Mudstone Formation, Abay River Basin, Ethiopia. - Zentralblatt für Geologie und Paläontologie 1: 293-309. 
Schrank, E. 1999. Palynology of the dinosaur beds of Tendaguru (Tanzania) - preliminary results. - Mitteilungen aus dem Museum für Naturkunde Berlin, Geowissenschaftliche Reihe 2: 171-183.

Schudack, M. 1999. Some charophytes from the Middle Dinosaur Member of the Tendaguru Formation (Upper Jurassic of Tanzania). - Mitteilungen aus dem Museum für Naturkunde Berlin, Geowissenschaftliche Reihe 2: 201-205.

Schultze, H.P. 1966. Morphologische und histologische Ūntersuchungen an den Schuppen mesozoischer Actinopterygier (Übergang von Ganoid- zu Rundschuppen). Neues Jahrbuch für Geologie und Paläontologie, Abhandlungen 126: $232-314$.

- 1996. The scales of Mesozoic actinopterygians. In Arratia G. \& Viohl, G. (eds). Mesozoic Fishes - Systematics and Paleoecology: 234-259, Verlag Dr. Pfeil, München.

Schultze, H.-P. \& Arratia, G. 1989. The composition of the caudal skeleton of teleosts (Actinopterygii; Osteichthyes). - Zoological Journal of the Linnean Society, London 97: 189-231.

Smith, A. G., Smith, D. G. \& Funnell, B. M. 1994. Atlas of Mesozoic and Cenozoic coastlines. 99 pp., Cambridge University Press, Cambridge.

Thies, D. 1983. Jurazeitliche Neoselachier aus Deutschland und S-England. - Courier Forschungs-Institut Senckenberg 58: $1-116$.

- 1995. Placoid scales (Chondrichthyes: Elasmobranchii) from the Late Jurassic (Kimmeridgian) of northern Germany. - Journal of Vertebrate Paleontology 15: 463-481.
Thurmond, J. T. 1971. Cartilaginous fishes of the Trinity Group and related rocks (Lower Cretaceous) of north central Texas. - Southeastern Geology 13: 207-227.

Underwood, C. \& Rees, J. In press. Selachian faunas from the earliest Cretaceous Purbeck Group of Dorset, Southern England. - Special Papers in Palaeontology.

Underwood, C. \& Ward, D. J. In press. Environmental distribution of Bathonian (Middle Jurassic) neoselachians in southern England. - Mesozoic Fishes 3.

Wagner, A. 1862. Monographie der fossilen Fische aus den lithographischen Schiefern Bayern's. - Abhandlungen der königlich-bayerischen Akademie der Wissenschaften, mathematisch-physikalische Classe 9: 279-352.

Wenz, S. 1999. Pliodetes nigeriensis, gen. nov., sp. nov., a new semionotid fish from the Lower Cretaceous of Gadoufaoua (Niger Republic): phylogenetic comments. In Arratia, G. \& Schultze, H.-P. (eds). Mesozoic Fishes 2 - Systematics and Fossil Record: 107-120, Verlag Dr. F. Peil, München.

Woodward, A. S. 1889. Catalogue of the Fossil Fishes in the British Museum (Natural History). Part I Elasmobranchii. xlvii + 474 pp., British Museum of Natural History, London.

- 1890. The fossil fishes of the Hawkesbury Series at Gosford. - Memoirs of the Geological Survey of New South Wales (Paleontological series) 4: 1-56.

- 1916. The fossil fishes of the English Wealden and Purbeck formations. Part 1. - Monographs of the Palaeontological Society of London: $1-48$.

Zangerl, R. 1981. Chondrichthyes I. Paleozoic Elasmobranchii. In Schultze, H.-P. (ed.). Handbook of Paleoichthyology 3A: 1-115. G. Fischer Verlag, Stuttgart. 